\title{
A critical review of fear tests used on cattle, pigs, sheep, poultry and horses
}

\author{
B. Forkman ${ }^{\mathrm{a}, *}$, A. Boissy ${ }^{\mathrm{b}}$, M.-C. Meunier-Salaün ${ }^{\mathrm{c}}$, E. Canali ${ }^{\mathrm{d}}$, R.B. Jones ${ }^{\mathrm{e}}$ \\ a Department of Large Animal Sciences, Roy Vet Agricult Univ, 1870 Frederiksberg, Denmark \\ b INRA, UR1213 Herbivores, Site de Theix, F-63122 Saint-Genès-Champanelle, France \\ c INRA Agrocampus, UMR1079, Systèmes d'Elevage et Nutrition Animale et Humaine, F-35590, Saint-Gilles, France \\ d Istituto di Zootecnica, Veterinary Medicine, 20133 University of Milan, Italy \\ e Consultant in Animal Welfare, Edinburg EH9 $3 H$ H, Scotland
}

Received 20 February 2006; received in revised form 13 March 2007; accepted 16 March 2007

\begin{abstract}
FORKMAN, B., A., BOISSY, M.-C., SALAÜN, E., CANALI, AND R.B., JONES. A critical review of fear tests used on cattle, pigs, sheep, poultry and horses. PHYSIOL. BEHAV. 000-000, 2007.

Fear is arguably the most commonly investigated emotion in domestic animals. In the current review we attempt to establish the level of repeatability and validity found for fear tests used on cattle, pigs, sheep and goats, poultry and horses. We focus the review on the three most common types of fear tests: the arena test (open field), the novel object test, and the restraint test. For some tests, e.g. tonic immobility in poultry, there is a good and broad literature on factors that affect the outcome of the test, the validity of the test and its age dependency. However, there are comparatively few of these well defined and validated tests and what is especially missing for most tests is information on the robustness, i.e., what aspects can be changed without affecting the validity of the tests. The relative absence of standardized tests hampers the development of applied ethology as a science.
\end{abstract}

(C) 2007 Elsevier Inc. All rights reserved.

Keywords: Fear; Cattle; Sheep; Pig; Poultry; Horse; Open field; Tonic immobility; Novel object

\section{Part 1 - Justification and background}

Fear and anxiety are two closely related emotions. Fear is generally defined as a reaction to the perception of actual danger, whereas anxiety is defined as the reaction to a potential danger that threatens the integrity of the individual [1]. Fearrelated reactions are characterized by physiological and behavioral reactions preparing the animal to deal with the danger. From an evolutionary standpoint, defensive reactions promote fitness in wild animals: the life expectancy of an animal is obviously increased if it can react to avoid sources of danger such as predators. Although natural predators are largely absent for animals kept in captivity the mechanisms and the emotion persists, together with the behavioral responses (e.g. [2]). In addition populations of domestic animals reared in range environments may still experience severe predation by wild animals or dogs (e.g. [4]). Routine management procedures can

\footnotetext{
* Corresponding author. Tel.: +45 3528 3581; fax: +45 35283022 .
}

E-mail address: bjf@kvl.dk (B. Forkman). elicit fear-related responses. For example, shearing, castration, tail docking, dehorning, vaccination, herding and transportation have been reported to be stressful to cattle and sheep $[5,6]$. Moreover, predator-avoidance behaviors against humans are still observed in farm species, though reduced fear of human beings is generally considered to be a major component of domestication [7]. In addition, besides its influence on the responses towards potentially dangerous situations, excessive fear may also lead to develop chronic stress known to alter fundamental behaviors (social, sexual and parental relationships) and reduce productivity in domestic herbivores. For instance, fear-related reactions affect sexual and maternal behaviors and social dominance ability in cattle and sheep $[8,9]$. Reducing the frequency of potential aversive events or providing additional positive experiences to the animals, such as handling or training (reviewed by Hemsworth and Coleman [10]) may help to make the environment more suitable for livestock. It may also allow adjusting animal fearfulness, defined as the propensity to experience fear or anxiety [5]. In addition, heritability of fearfulness has been reported in 
laboratory species (reviewed by Ramos and Mormède, [11]) and in farm species (reviewed by Boissy et al. [12]). Therefore, environmental strategies and genetic selection both aimed at reducing fearfulness might be of economic and ethical significance for livestock production.

\subsection{Diversity in the nature of fearful events}

According to Gray [13], the fear-eliciting nature of an event is due to the general characteristics of the event, e.g. novelty and physical characteristics of its presentation, such as movement, intensity, duration, suddenness or proximity. Fear may be also be elicited by specific stimuli, such as height and darkness, in relation to the evolutionary history of the species (ancestral fears/innate fears). In addition, an event can elicit fear by being associated by previous experience with another fearful event (conditioned fear). Since the major characteristic of farm animals is their gregariousness [14], fear may be induced through a variety of social stimuli. Triggering social signals can represent particular cases of the previous types of fear-eliciting stimuli. Some social signals are characterized by their novelty, as the novelty of the neonate that affects maternal behaviour in primiparous females [15]. Other social signals, such as odors or alarm calls, can spontaneously elicit fear [16]. Triggering social signals may also be acquired, as threats in the case of dominance hierarchies [8]. In addition, social isolation is probably one of the most important stressful components for all social species that are generally tested individually for measuring fear. Various studies suggest that most of the domestic species have a high social motivation and consequently may suffer more from separation anxiety than from the fear-eliciting event per se.

\subsection{Diversity in fear-related responses}

Behavioral patterns related to fear vary greatly depending on the characteristics of the threat. They can be contradictory, since both active and passive strategies are observed in challenging situations: active defense (attack, threat) or active avoidance (flight, hiding, escape) and passive avoidance (immobility) can be viewed as expressing fear [17]. Other behavioral patterns can also be considered as fear indicators, including some expressive movements, such as postures of the head and facial expressions, and some specific alarm calls, as well as odors or pheromones. These behavioral patterns play an important part in the social communication of herbivores by serving as signals to alert conspecifics. Fear-eliciting stimuli may also affect the activity in which the animal is engaged. When the level of fear is low, the activity may be enhanced: the administration of weak electric shocks leads to an increase in food intake. In contrast, when fear is intense, the activity can be disturbed or totally inhibited: regular noxious stimuli inhibit social interactions between animals. Finally, conflict between a negative emotional state and a positive motivation may result in a compulsive behaviour such as nibbling of a chain. The activation of the sympathetic nervous system-adrenal medulla and the hypothalamic-pituitary-adrenal system are the main neuroendocrine responses associated with negative emotions (reviewed respec- tively by von Borrel et al. [18] and Mormède et al. [19] in this volume). A range of complex central nervous mechanisms, such as neural pathways and neurotransmitters, that occurred during fearful situations have also been widely studied (reviewed by Gray, [13]).

\subsection{Variety of experimental designs}

The experimental situations that have been designed to study fear in farm animals are various. For the most of them, they were originally developed for laboratory species. Since the classic work of Hall in 1936 [20], the open-field or novel arena test has been extensively used in rodents [21]. Generally, a single animal is placed in a large novel area and the amount of defecation and activity is interpreted as reflecting the response to novelty. Subsequent work has shown that this test provides a number of other threatening events, such as absence of shelter and landmarks, social isolation and bright lighting. Many other tests were devised to assess fear in rodents, such as exposure to a predator or a novel object, confinement, handling by humans, administration of inescapable noxious stimuli, and passive or active avoidance conditioning [22]. This is only more recently that most of these experimental paradigms were used in domestic animals. The open-field design, commonly called "Novel Arena test" (NAT), is applied to a wide range of farm animals, such as ruminants, pigs, horses and poultry. Fear of novelty is also evaluated through the exposure to a novel object ("Novel Object test", NOT). The exposure to a human has been specifically developed for farm animals to study their fearrelated responses, with the animal that is either approached by a human ("Forced Approach test", FAT) or is free to approach a human ("Voluntary Approach test", VAT). Confinement is also widely used in farm animals ("Tonic Immobility test", TI and "Restraint test", RT). Fear tests based on exposure to human tend to use forced vs. voluntary approach tests uncritically. According to Waiblinger et al. [23], the forced approach test would probably increase the likelihood that an animal will respond more actively to the human whereas in the voluntary approach test, the chances of getting no response or a passive response would probably be higher. Finally, fear is also evaluated from the responses of the animals exposed either to a natural predator of the given domestic species ("Predator test", PT), or to a sudden sound or a visual stimulation ("Startle test", $\mathrm{ST}$ ), or to a signal that had been previously associated with a nociceptive event such as electric shock ("Conditioned Fear test", CER).

\subsection{The complexity of fear responses}

Behavioral and endocrine reactions to fearful events are only indicators of fear and cannot be considered as direct measures of a subjective state of fear. Because of the complexity of the mechanisms underlying fear-related responses, it is not possible to attribute a given behavior to any single emotion [1]. For instance, in cattle, the response to a novel object depends on the experimental designs. When the cows voluntarily approach the novel object, the most reactive animals to humans have the 
strongest tendency to approach it; by contrast, when the cows are forced to move toward the same novel object, just the opposite is true [24]. Therefore, a measurement used as an emotional indicator in one situation cannot be extrapolated directly to others, and it is impossible to assess simply the magnitude of concepts like fear on the basis of a single "objective and perfect" measurement.

\subsection{The absence of validation in experimental designs}

Apart for the tests implicating an exposure to humans, most of the tests used in farm animals for measuring fear have been previously designed for laboratory animals. However, such tests were generally used in applied ethology without taking into account their biological significance for farm animals. Clearly, there are limitations in extrapolating experimental paradigms between lab animals and domestic species, since differences of ecological characteristics and motivations across species have been identified. Laboratory animals are nocturnal whereas most domestic animals are diurnal. Laboratory animals show thigmotaxis whereas domestic animals often come from open areas (is open field in cattle an example of closed field?). In farm animals, young animals are generally precocious and the social dimension is extremely developed in most of farm animals that are highly gregarious and present exclusive mother-young relationship. Therefore, testing animals in inappropriate environments - that is likely to result in abnormal and maladaptive behaviour - can lead to an inaccurate estimation of fear and may explain the lack of links between studies. A reconsideration of the ecological context of the domestic species has to be conducted in order to elaborate and to validate more realistic conditions of fear stimulation.

In addition, studies in lab animals could shed light on how to better interpret the range of emotional reactions experienced by farm animals in aversive situations. A few studies in lab animals emphasize the relationship between emotions and cognition by showing how mental operations of evaluation are required to produce emotional reactions (reviewed by Boissy et al. in this volume [25]). In addition to suddenness, unfamiliarity and unpredictability, the ability to cope with the challenging event can change the perception of the animal. Various forms of evaluative processing, ranging from rapid to subtle, occur to differentiate the emotional experiences. Suddenness, unfamiliarity and unpredictability have been recognized to produce, or at least affect, fear reactions of animals. For instance, sudden or unfamiliar events are often used in various species to assess the animals' fearfulness [1]. From an ecological point of view, suddenness, unfamiliarity and unpredictability are the key features of a predatory attack, and domestic ungulates in range environments may still experience predation by wild animals or dogs [26]. Tests for suddenness use the presentation of a stimulus such as a ball falling suddenly from the ceiling in front of the animal [27] or a blast of compressed air applied on the muzzle [28]. As reported earlier, unfamiliarity is always included in the so-called open-field test. Finally, the unpredictability of an aversive stimulus is known to enhance stress responses [29]. For instance, in rats, the corticosterone response to repetitive exposure to a novel cage is more pronounced when the exposures are irregular than regular [30]. Not only aversive stimuli but also the unpredictability of pleasant stimuli can affect fear in animals. For instance, rats present stress-induced analgesia when food delivery is unpredictable [31]. More generally, measures of cognitive processes, such as anticipation, can provide information about animal emotion: anticipatory behavior measured in a Pavlovian conditioning paradigm has been identified in rodents as a potential indicator of emotion [32]. In addition to the intrinsic characteristics of the challenging event (i.e., its suddenness, unfamiliarity and unpredictability), the ability to cope with the event can change the emotional experience of the animal. For instance in cattle, the response to a novel object depends on the environmental context. When cows voluntarily approach a novel object, the most reactive ones to humans also have the strongest tendency to approach the object; but when the cows are forced to move toward the same novel object, the opposite is observed [24]. Therefore, the definition of experimental situations according to the basis of the evaluation abilities of the animals should help to interpret the variety of behavioral and physiological responses, and thus to better access the emotional world of these latter.

The absence of current validation in experimental designs and the lack of standard protocols are hampering research into fear today. This review is an attempt to organize the methodology used to assess fear in farm animals. The species included in the review are: cattle, pig, sheep and goats, chicken and quail, and horse. The methods are briefly described, and the repeatability and validity for each test in each species given. Because of the recent publication of a review on human animal interaction [23] the tests involving human contact have not been included in the present review. Additional information concerning the stability of the test, i.e. the effect of minor changes in the procedure, is discussed.

Discussing the efficiency of the most frequently used experimental designs for measuring fear in domestic animals is essentially based on two criteria, which are validity and reliability. Validity refers to the relation between a measured variable and what it is supposed to predict. Martin and Bateson [33] defined validity by accuracy (i.e., the degree of freedom from systematic errors that might over- or underestimate the measured variable), specificity (i.e., the extent to which a measured variable reflects what it is supposed to and nothing else) and scientific validity (i.e., the extent to which the method gives relevant information and answers to the hypothesis). Reliability is defined by Martin and Bateson [33] as being the degree to which measures are free from random errors. It is partly determined by the repeatability or the consistency of the measures (i.e., repeated measures of the same construct should produce the same result). Assessing repeatability for validating fear tests is a real unresolved problem. Because animals can react differently, some may habituate to the test-situation and some others may lower their threshold for expressing fear after being subjected to the same test situation several times. This is truer when taking into account tests based on novelty since test situations are not novel from the second exposure: Should we expect a habituation process that takes to reduce fear responses 
Table 1

Novel arena test of cattle

\begin{tabular}{|c|c|c|c|c|c|c|c|c|}
\hline \multirow[t]{3}{*}{ Reference } & \multirow{3}{*}{$\begin{array}{l}\text { Arena size } \\
(\mathrm{m})\end{array}$} & \multirow{3}{*}{$\begin{array}{l}\text { Time } \\
(\mathrm{min})\end{array}$} & \multirow{2}{*}{$\begin{array}{l}\text { Age } \\
\text { Sex } \\
\end{array}$} & \multirow{2}{*}{$\begin{array}{l}\text { Replicate, } n \\
\text { interval/test } \\
\text { - Within } \\
\end{array}$} & \multirow[t]{3}{*}{ Variables } & \multicolumn{2}{|l|}{ Validity } & \multirow[t]{3}{*}{ Procedures and other factors } \\
\hline & & & & & & \multirow[t]{2}{*}{ Internal validity } & \multirow[t]{2}{*}{ External validity } & \\
\hline & & & Breed & - Between & & & & \\
\hline \multirow[t]{2}{*}[45]{} & $22 \mathrm{~m}^{2}$ & 5 & Cows & 3 rep & $\begin{array}{l}\text { No: squares entered, } \\
\text { defecations, urinations, voc }\end{array}$ & Corr between movement and voc & $\begin{array}{l}\text { No relationship between } \\
\text { movement or vocalization } \\
\text { and temperament ratings }\end{array}$ & Preliminary tests 6 days for $15 \mathrm{~m}$ \\
\hline & & & $\begin{array}{l}\mathrm{F} \\
\text { Jersey }\end{array}$ & No interval & & Consistency between rep & & Temperament ratings \\
\hline \multirow[t]{3}{*}[46]{} & $9 \times 9$ & 30 & Cow & $\begin{array}{l}6 \text { rep } \\
\text { (2 each day) }\end{array}$ & No: squares entered & Decrease in activity after $10 \mathrm{~min}$ & Increase pulse frequency & $\begin{array}{l}\text { Pulse frequency, food dispenser } \\
\text { in the arena }\end{array}$ \\
\hline & & & $\mathrm{F}$ & No interval & Dur: total time movement & & No corr with production & Noise as stressor \\
\hline & & & Different breeds & & & & & \\
\hline \multirow[t]{3}{*}[47]{} & $10 \mathrm{~m}^{2}$ & 5 & $9-15$ months & & Lat: latency to enter & & $\begin{array}{l}\text { Consistency between test } \\
\text { and cortisol and HR }\end{array}$ & 1 min latency \\
\hline & & & F & & $\begin{array}{l}\text { No: squares entered, sniff., voc., } \\
\text { defecations, urination, attempts to } \\
\text { escape, trot, gallop }\end{array}$ & & $\begin{array}{l}\text { No relationships between } \\
\text { NAT and other tests }\end{array}$ & PCA \\
\hline & & & Friesian & & Other: cortisol levels, heart rate & & & Also tested with VAT, FAT, RT \\
\hline \multirow[t]{3}{*}[48]{} & $8 \times 8$ & 5 & Cows & 2 rep & Lat: entrance and exit & $\begin{array}{l}\text { Neg correl between } \mathrm{n} \text {. } \\
\text { square crossed moving time, } \\
\text { sniffing and exit latency ; }\end{array}$ & $\begin{array}{l}\text { Salers heart rate pos } \\
\text { correlated with activity }\end{array}$ & $\begin{array}{l}1 \text { min latency, } \\
3 \text { min after test }\end{array}$ \\
\hline & & & $\mathrm{F}$ & 1 year & $\begin{array}{l}\text { No: squares crossed, sniff, voc., } \\
\text { defecations, urinations, } \\
\text { times looking at observer, } \\
\text { contacts with wall }\end{array}$ & $\begin{array}{l}\text { neg corr between moons } \\
\text { def, urine and time sniffing }\end{array}$ & $\begin{array}{l}\text { Rel between behaviour } \\
\text { and activity in NAT }\end{array}$ & $\begin{array}{l}\text { heart rate and respiratory rate, } \\
\text { observation at pasture, }\end{array}$ \\
\hline & & & Salers, Friesia & & $\begin{array}{l}\text { Dur: total moving time, } \\
\text { time spent near entrance } \\
\text { time spent in the centre }\end{array}$ & & & PCA analysis \\
\hline \multirow[t]{3}{*}{ [49] } & $24 \mathrm{~m}^{2}$ & 5 & Heifers & & Lat: entrance and exit & & No relationship between tests & I min in another pen \\
\hline & & & $\mathrm{F}$ & & $\begin{array}{l}\text { No: zones crossed, sniff. lick, voc, } \\
\text { urination, defecation, selflicks }\end{array}$ & & & Handling test \\
\hline & & & Different breeds & & Dur: time spent in each zone & & & Also tested with RT \\
\hline \multirow[t]{3}{*}[50]{} & $4 \times 4$ & 10 & Heifers & 3 rep & No: voc. & & $\begin{array}{l}\text { Lack of inter-correlations } \\
\text { between tests. Corr. } \\
\text { locomotion between repeats }\end{array}$ & PCA analysis \\
\hline & $4.5 \times 4.5$ & & $\mathrm{~F}$ & 13 weeks & Dur: locom, sniff or touch floors & & & Also tested with NOT, VAT, RT \\
\hline & $6 \times 6$ & & Friesian & & & & & \\
\hline \multirow[t]{3}{*}[51]{} & $3 \times 4.5$ & 10 & Calves/Heifers & 3 rep & Lat: to enter & & $\begin{array}{l}\text { Pos corr avoidance } \\
\text { responses OF and cortisol }\end{array}$ & $\begin{array}{l}\text { Cortisol response to ACTH, } \\
\text { ACTH and cortisol response to } \\
\text { CRH, HR }\end{array}$ \\
\hline & $6 \times 6$ & & $\mathrm{~F}$ & $3-13$ weeks & No: voc., defecation, urination & & & PCA analysis \\
\hline & & & Friesian & & Dur: locom, sniff or touch floors & & & Also tested with NOT \\
\hline
\end{tabular}

(continued on next page) 
Table 1 (continued)

\begin{tabular}{|c|c|c|c|c|c|c|c|c|}
\hline \multirow[t]{3}{*}{ Reference } & \multirow{3}{*}{$\begin{array}{l}\text { Arena size } \\
(\mathrm{m})\end{array}$} & \multirow{3}{*}{$\begin{array}{l}\text { Time } \\
(\mathrm{min})\end{array}$} & \multirow{2}{*}{$\begin{array}{l}\text { Age } \\
\text { Sex } \\
\end{array}$} & \multirow{2}{*}{$\begin{array}{l}\text { Replicate, } n \\
\text { interval/test } \\
\text { - Within } \\
\end{array}$} & \multirow[t]{3}{*}{ Variables } & \multicolumn{2}{|l|}{ Validity } & \multirow[t]{3}{*}{ Procedures and other factors } \\
\hline & & & & & & \multirow[t]{2}{*}{ Internal validity } & \multirow[t]{2}{*}{ External validity } & \\
\hline & & & Breed & - Between & & & & \\
\hline \multirow[t]{3}{*}[28]{} & $10 \times 10$ & 5 & $\begin{array}{l}\text { Heifers } \\
18 \text { months }\end{array}$ & & Lat: to enter, to exit, & $\begin{array}{l}\text { Corr. between different expression } \\
\text { of fear in the single tests }\end{array}$ & $\begin{array}{l}\text { Latency to exit and immobility in } \\
\text { NAT pos corr with latency to } \\
\text { approach n.o. and time spent } \\
\text { away from it, locomotion and } \\
\text { voc. pos corr with sniff n.o. }\end{array}$ & Conflict test fear and feeding \\
\hline & & & $\mathrm{F}$ & & $\begin{array}{l}\text { Dur: immobility, } \\
\text { immobilization bouts }\end{array}$ & & & 1 min undisturbed \\
\hline & & & Friesian & & $\begin{array}{l}\text { No: head position, squares } \\
\text { entered, voc. }\end{array}$ & & & Also tested with NOT, ST \\
\hline \multirow[t]{2}{*}[42]{} & $11 \times 3.2$ & 15 & $5-15$ weeks & 2 rep & $\begin{array}{l}\text { Dur: immobile, walk, } \\
\text { run, sniff/lick }\end{array}$ & $\begin{array}{l}\text { First factor positive loading } \\
\text { sniff/lick neg. for immobile }\end{array}$ & $\begin{array}{l}\text { Heart rate increase during } \\
\text { NAT related to activity }\end{array}$ & $\begin{array}{l}15 \text { min exploration of the arena } \\
\text { for } 3 \text { days, } 1 \mathrm{~h} \text { exercise before } \\
\text { test, familiar and unfamiliar person } \\
\text { in the arena, factor analysis }\end{array}$ \\
\hline & $6 \times 2.7$ & & $\mathrm{~F}$ & 10 weeks & $\begin{array}{l}\text { No: immobile, walk, run, jump, } \\
\text { sniff/lick, voc. defecations, other }\end{array}$ & $\begin{array}{l}\text { Relationship between def } \\
\text { and time spent walking }\end{array}$ & & \\
\hline \multirow[t]{3}{*}{ [52] } & $7.2 \times 2.4$ & 10 & $\begin{array}{l}\text { Holstein } \\
3-6 \text { months }\end{array}$ & 2 rep & Lat: sniff the wall, sniff calf & $\begin{array}{l}\text { Changes with the age no stability } \\
\text { Inverse relationship between } \\
\text { immobility and exploration. } \\
\text { No corr between two sessions of } \\
\text { tests. Changes with age }\end{array}$ & $\begin{array}{l}\text { PCA reflecting exploration and } \\
\text { fear were found in the two tests }\end{array}$ & $\begin{array}{l}\text { NAT alone or with } \\
\text { unfamiliar calf in the arena }\end{array}$ \\
\hline & $4.8 \times 4.6$ & & $\mathrm{~F}$ & 3 months & $\begin{array}{l}\text { Dur: immobile, time in central } \\
\text { square,, sniff., run., } \\
\text { No: voc., def., squares entered }\end{array}$ & & & \\
\hline & & & Calves & & & & & \\
\hline \multirow[t]{2}{*}{ [53] } & $\begin{array}{l}\text { L shaped } \\
28.8 \mathrm{~m}^{2}\end{array}$ & 10 & $2-10-25$ weeks & 3 rep & Lat: to enter the arena & $\begin{array}{l}\text { High neg. corr. between time } \\
\text { spent immobile and time sniffing, } \\
\text { moderate neg corr. between time } \\
\text { spent immobile and and square } \\
\text { entered No correlation between } \\
\text { the tests }\end{array}$ & & 1 min latency, \\
\hline & & & $\begin{array}{l}\text { F } \\
\text { Danish Holstein } \\
\text { Friesian calves }\end{array}$ & $8-14$ weeks & $\begin{array}{l}\text { Dur: standing immobile } \\
\text { No:, sniffing, running bucking, } \\
\text { squares entered }\end{array}$ & & & Preference test \\
\hline
\end{tabular}


Holstein

No interval

$\begin{array}{lll}3 \times 12 & 5 & \mathrm{M} \\ & & \mathrm{Ho}\end{array}$

$12 \mathrm{~m}^{2}$

$\mathrm{M}$ 54,8 weeks

F

Ottonese,

Friesian

$9 \times 7$

$15 \quad 4-7$ months

F

Swedish Red

and White

[42]

$4.4 \times 3 \quad 3 \quad 2-6$ weeks

$\begin{array}{ll}\mathrm{M} & 1 \text { month } \\ \text { Friesian } & \end{array}$

[43]

6-8 months

\section{2 rep}

1 month

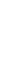

Lat: first movement

Dur: immobility

No: squares entered, voc.

stereotyped beh

No: squares entered, voc,

defecations, urination

Higher cortisol after the test

Plasma total cortisol,

dominance value, $\mathrm{ADG}$, WW

No: Trot, canter, buck-kick,

two types of voc, social

encounters, incidence of

stumbling and falling

\section{Lat: Spontaneous entry}

Dur: freezing, , sniff

No: defecations, urination,

movements, location of

movement, attemps to escape

Lat: to enter

Dur: passive, standing

No: squares entered, walking,

running, voc., exploration,

tail position, urination, defecations

Lat: sniff, lick surrounds
No differences between 2
and 6 weeks

Bucking and cantering

decreased over the test period

\section{No correlation between 2 \\ and 3 months}

No correlation with

weight or age

Pos corr between stereotypies

and exploration

High stereotypies and

least square entered

Moderate repeatability

between rep

Pos corr between

Square entered and

escape attempts

Calves put on a trolley

Tested with alien calf

Feeding behaviour

weight, dominance value

Behavioral recording, adrenal

test, 5 min starting box

Total distance travelled

Escape attempts
Other: ACTH stimulation, Cortisol

Abbreviations: Lat. = latency, Dur. = duration, No. = number, Corr. = correlation, PCA = principal component analysis.

Abbreviations for the tests: NAT $=$ novel arena test, NOT $=$ novel object test, RT $=$ Restraint test, VAT $=$ voluntary approach test, FAT $=$ forced approach test. 
of the animals in the same test, or should we expect an opposite process, a sensitization over time, that takes to increase their fear responses? Therefore, we can raise the relevance of evaluating intra-test consistency over time by repeating the same fear test several times. In order to validate experimental designs for measuring fear, it would be better to study the only first and immediate responses of animals, and by studying putative correlations between these reactions to various biologically related situations (i.e., inter-test consistency), as for example by using different novel stimuli. In addition, recording micro-behavioral expressions, such as posture of the head and the tail, and some specific alarm calls - these patterns play an important part in the social communication by serving as signals to alert conspecifics [8] - and at the same time defining experimental situations according to the evaluative abilities of the animals may provide considerable information about an animal's fear state and its real perception of the external situations. Many studies in lab animals provide convincing evidence for a consistency in the individuals' responses across different aversive situations. Brush and coworkers [34] reported that rats exhibiting low performance during active avoidance conditioning have a higher defecation rate in open-field. The defecation rates recorded on rats subjected to a conditioned fear then to an open-field are positively correlated [35]. Good correlations among responses to a few kinds of aversive stimuli are also obtained in dogs [36]. Likewise, numerous correlations are found in birds among reactions to open-field, emergence and tonic immobility tests in chicks [37], hens [38] and Japanese quails [39]. Concerning domestic ungulates, several correlations are found between behavioral patterns reflecting fear in different aversive situations: variables which express a high level of fear, are positively correlated through the various tests and negatively correlated with those expressing a low level of fear (heifers: [40]; sheep: [27,41]. Taken together, there is a strong tendency for individual characteristics to manifest themselves across a variety of aversive situations. Validation throughout inter-test consistency should thus be given more attention in futures studies.

\section{Fear tests in cattle}

The most commonly used fear test in cattle is the novel arena test, novel object and the voluntary approach, forced approach and different type of restraint tests are less used (Table 1). These tests are usually done one by one, but in some studies combined tests are carried out for example by including a novel object or a human, another calf or food in the novel environment right from the start $[28,42,43]$.

\subsection{Novel arena test}

\subsubsection{Background}

This test is often used in calves, heifers and cows and the variables most commonly recorded are: latency to enter and to leave the arena, locomotor activity (number of square entered, standing, walking), exploration (sniffing) eliminative behavior (defecation, miction), vocalizations [45], and escape attempts
[44]. The arena varies from $10-12 \mathrm{~m}^{2}$ for calves and heifers up to $100 \mathrm{~m}^{2}$ for cows. The arena has usually solid wall up to $2.6 \mathrm{~m}$. Not only the size and the location (outdoor vs. indoor) but also the shapes differ among the studies. The time spent in the arena varies between 3 and $30 \mathrm{~min}$. As already reviewed by [59] the duration of the test may influence the results obtained in the arena. Handling procedures and latency to enter the arena differ between authors. Cattle are tested at different ages: calves from 2 weeks of age since 6 months, heifers were tested at 15 and 18 months of age and in some studies cows were tested. The open-field test is sometime combined with others tests performed thereafter within the same arena or restraint test, or with behavior expressed in their pen. In the majority of the experiments the animals are tested alone, and only rarely in the presence of another calf.

\subsubsection{Repeatability}

The question of the relevance to expose repeatedly individuals to the same experimental designs when they are based on novelty has already been raised in the general background. Nevertheless, some open field studies reported intra-test consistency over time when the repetitions between tests are close and in cows $[45,46]$ while in calves there were no stability [42]. The most repeatable variables are movement, vocalizations, time spent immobile and exploration but at various levels according to studies. Locomotion seems more related to activity than fear of novelty in heifers [28] and to social isolation in calves [42]. The repeatability studies have used very different time intervals, from no interval [45] to 1 year [48] and in all cases the animals were tested alone.

\subsubsection{Validity}

The overall picture is that the behavior of cattle in an open field situation does correlate with their behavior in other fear tests, at a low level $[28,52,44]$ or not at all, there are no correlations with reactions to humans. $[45,47,49]$.

\subsubsection{Conclusion}

Because of the lack of strong correlation with other tests of fear the open field test can not be recommended as a general fear test for cattle. The repeatability for some of variables is good and the test seems to capture some part of the behavioral tendencies of an individual animal. However care should be taken in the interpretation of the test results. As pointed out [48] results are very difficult to understand and many factors can lead to the same activity in the open field. This is the case of locomotion which can reflect fear but also investigation. For this reason correlations among behaviors or multivariate analysis could help in the interpretation of the different motivations. Social motivation can be the primary factor affecting the open arena behavior, especially when group-reared animals are tested individually [59]. Moreover the lack of consistency of responses over time may result an altered motivation over time (related or not to the rearing systems) or an habituation effect. The perception of the novel environment seem to change by aging (older calves are more active in open-field [49]). These changes may also occur when tests are repeated close in time. 
On the other hand methodological problems can arise with repeated tests at long time span with the size of arena unadjusted to the changes in the body size of an animal. This test could be useful only as complementary test or to study other motivation such as the need for locomotion in confinement situation [53].

\subsection{Novel object test}

The novel object test is seldom used independently in cattle, more commonly it is performed in the same pen used as a previous open-field test where different tests are combined. The novel stimulus tested are usually visual, an object introduced by human on the floor before the habituation period within the arena $[61,28]$, or dropped from the ceiling and left on the floor or after [62]. Cattle are tested alone. Habituation period to the test arena before the confrontation to a novel object varies between 1 and $15 \mathrm{~min}$. Animals are tested at very different age calves and heifers. The variables most commonly recorded indicated the interest towards the novel stimulus measured by the latency to the contact, distance from the novel object, frequency or duration of contact, exploration (licking, smelling), body posture, vocalizations (Table 2).

\subsubsection{Repeatability}

One study have 8 repetitions at 1 -week interval [61] but novel object test was done at the same time of the open field test, the authors found a decrease in the exploratory behavior in general. In another study the test was repeated three times at 3-4 weeks of interval and there was a decline in the interactions with novel object and the coefficient of repeatability was near to zero [44].

\subsubsection{Validity}

One study found a positive correlation between latency to exit the room and latency to approach novel object $(\mathrm{Rho}=0.50)$ and a negative correlation between latency to exit the room and

Table 2

Novel object test in cattle

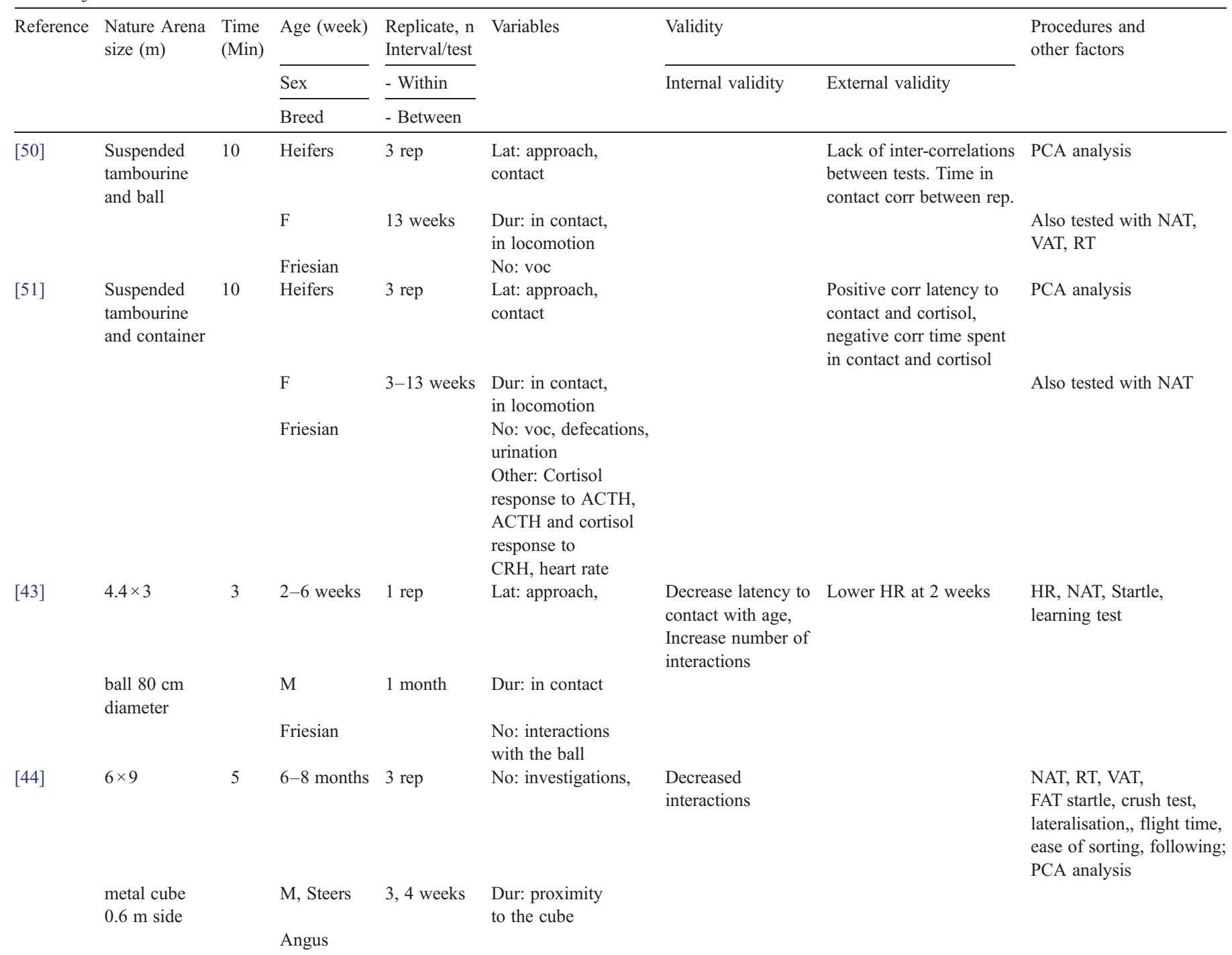

Abbreviations: Lat. $=$ latency, Dur. $=$ duration, No. $=$ number, Corr. $=$ correlation, $\mathrm{PCA}=$ principal component analysis.

Abbreviations for the tests: NAT $=$ novel arena test, NOT $=$ novel object test, RT $=$ Restraint test, VAT $=$ voluntary approach test, FAT $=$ forced approach test. 
time spent sniffing the novel object $(\mathrm{Rho}=-0.49)$ [20]. While locomotion in open field was positively correlated with time spent sniffing the object $(\mathrm{Rho}=-0.53)$ and vocalizing $($ Rho $=-0.59)$.

\subsubsection{Conclusion}

There is very little done on novel substrate, and more work needs to be done before it can be said that it is a valid test.

\subsection{Other tests}

Only three papers used handling test and other fear test such as the novel area test $[49,47,44]$. Handling tests involve human presence and consequently combine the potential stressful trait of the procedure of handling and the fear towards human. The animals were tested with the presence of conspecifics or individually. Various procedures were used in the handling tests including husbandry practice such to be separated by peers or the restraining it in a specific area or haltering, leading and tethering. In handling test the variables most commonly recorded concerns the ease, the attempts and time necessary to be separated from the other animals and the responsiveness to restraint both expressed as scores including motor reactivity.

\subsubsection{Repeatability - validity}

There is a consistency between tests and physiological parameters [47] but no relationships between tests [49] possibly due to different tests used and different breeds.

\subsubsection{Conclusion}

Type of handling and the human involvement in the handling procedures need to pay attention on the interaction between the confidence level of tested animals towards the handler and the responsiveness to handling itself and the importance of conspecifics during the tests.

\section{Fear tests in pigs}

The most commonly used fear tests in pigs are the open field, novel object and the voluntary approach tests. These tests are usually done one by one, but in many studies combined tests are carried out for example by letting a novel object fall into the open field arena after an habituation period within the test arena, or by including a novel object or a human in the novel environment right from the start. More recently new tests have been developed such as the back test, elevated-plus-maze test (EPM) or Dark/Light Test (D/L).

\subsection{Novel arena test}

\subsubsection{Short background}

This test is often used in pig [63] and the variables most commonly recorded are: locomotor activity (lying, standing, and exploration), eliminative behavior (defecation, miction) and vocalizations (squeals, grunts). The arena is usually between 5 to $10 \mathrm{~m}^{2}$ for piglets (up to 8 weeks of age), adjusted to the body length of tested animals especially for older animals. The time spent in the arena varies between 5 and $20 \mathrm{~min}$. In some cases a walkway or an alley just outside the box is used as an open field arena with "unusual" dimensions, very long and narrow, e.g. $1 \times 7 \mathrm{~m}$. Pigs are typically tested 1 or 2 weeks after weaning, or less frequently at older stage [64-66]. The open-field test was usually combined with others tests performed thereafter within the same arena $[67,65,68]$.

\subsubsection{Repeatability}

The results from the open field studies are consistent over time, with the most repeatable variables being activity and vocalizations but at various levels according to studies $[63,67,64]$. By contrast locomotion is more related to activity than fear of novelty and defecation does not represent a general response to frightening situation. The repeatability studies have used very different time intervals, from 2 days [67] to 18 weeks $[64,66]$ and in all cases the animals were tested alone. In a study in which the pigs were tested in group, the result deviates from those of other studies in that they did not find any consistency of behavior between tests [66].

\subsubsection{Validity}

The overall picture is that the behavior of pigs in an open field situation does correlate with their behavior in other fear tests, at low level $(\mathrm{rs}<0.36)$ or not at all $[65,69,71,66]$. Nor does the behavior in the open field appear to be sensitive to the administration of diazepam - a common anxiolytic that does affect the open field behavior in rodents [70]. In return positive correlations were reported between the adrenocorticol reactivity measured in an ACTH challenge and ambulation or vocalization scores [64]. Relationships were also reported between the openfield responses and the maternal behavior [65].

\subsubsection{Conclusion}

Because of the lack of strong correlation with other tests of fear the open field test can not be recommended as a general fear test for pigs. The repeatability for a number of variables is good and the test seems to capture some part of the behavioral tendencies of an individual animal. However care should be taken in the interpretation of the test results. Social motivation can be the primary factor affecting open-field behavior, at least when group-reared animals are tested individually. Moreover the lack of consistency of responses over time may result an altered motivation over time or a habituation effect. Although results suggested reduced fear related with a reduced threatening impact of leaving the home pen, it could be indicated an increased willingness to move from their home pen [72]. The perception of the novel environment may also be changed by aging, the animals becoming more experienced with various events. On the other hand methodological problems can be arise with repeated tests at long time span with the size of arena unadjusted to the changes in the body size of an animal.

In contrast to the often-described "emotionality" in laboratory animals characterized by freezing and defecation, the vocalization criteria give a relevant indication for the level of excitement in response to a novel situation. In further investigations the size 
of apparatus arena should be standardized or at least the size of a square, e.g. have it as the body length of the animal. In addition it should be important to pay attention before the test itself to the previous context especially when animals are tested outside their home pen, e.g. by training animals to move in free or limited stressful conditions to the test arena and to stay in the waiting box. Latency time to leave the home pen in the first test may be a useful measure of fear or timidity to leave the familiar environment [17].

\subsection{Novel object test}

\subsubsection{Short background}

The novel object test is often performed after a habituation period to a barren open arena used in some case as a previous open-field test when different tests are combined [73]. The test can be also performed in home pen $[74,68]$. The novel stimulus tested are usually visual, an object introduced by human on the floor after the habituation period within the arena or dropped from the ceiling and left on the floor. The visual stimulus is typically a bucket, colored (red) or bright. The novel substrate can also concern olfactory cues, as unfamiliar odor or ammoniac [75].

Animals are typically usually tested alone between 1 and 12 weeks after weaning, or more rarely older. Habituation period to the test arena before the confrontation to a novel object varies between 3 and 5 min or less. The arena is usually between 8 and $26 \mathrm{~m}^{2}$ for piglets or gilts ( 3 weeks -16 weeks). The novel test can also be performed in the home pen and combined with other tests [68]. The variables most commonly recorded indicated the interest towards the novel stimulus measured by the latency, frequency or duration of contact, exploration and attention without physical contact.

\subsubsection{Repeatability}

Studies have used very different time intervals, from few days [73] to 12 weeks [68]. It should explain various results on the consistency over time. Vocalizations and object investigation appeared repeatable when measured in gilts over few days during a 2-week period [73], whereas Jensen et al. [67] found no correlation in object investigation between repeated measures in piglets tested with 2 days between trials. When tests were carried out over a longer period ( 8 weeks-24 weeks) some consistency have been reported in duration and frequency of the object investigation ( $\mathrm{rs}=0.44$ and $\mathrm{rs}=0.53$ respectively; [78]). In studies where animals were tested in group no consistency of behavior between tests has been found in pigs tested twice at 5 week interval (8 weeks and 13 weeks; [68]).

\subsubsection{Validity}

Very few correlations have been reported between the response to novel object and others tests, including tonic immobility (back test), voluntary approach a human or social test with congeners. In the case of significant correlation between human and novel object responses it was observed at 8 weeks of age but not 24 weeks later, the lack of correlation being related with a potential estrus effect [78].

\subsubsection{Conclusion}

The discrepancy of results in consistency over time may reflect an altered motivation over time or an habituation effect. Factors such as time (development) and situation (test) may also an important role in determining an individual's behavioral reaction. Behavioral increased human and object investigation observed in older pig may indicate that fear and anxiety decrease with age. Results should also indicate that the willingness to explore new and 'dangerous' object is parted from exploring behavior directed to the environment and that reactivity and curiosity are connected. This point is important in the case of various objects introduced in successive tests [79] where the novelty repetition should provide an enriched environment and enhance or fulfill the investigative motivation. Furthermore the nature of the novelty-related stimulus may modulate the responsiveness to novelty. Indeed [80] reported strongest and most consistent aversive responses to auditory stimuli rather than olfactory ones in individual growing pigs exposed to stimuli in a test pen.

On the other hand, the novel tests were in some case combined with suddenness when the object are dropped from the ceiling and left on the floor. Similarly the novel tests are classically associated with human intervention when the object has to be introduced or remove at the beginning and the end of the test respectively. This can partly explained the existing correlation between repeated measures of human and object investigation in young animals.

It is important to evaluate in a novel test the specific underlying effects of novelty and suddenness during the test. In addition the habituation period to the arena test is generally neglected and arbitrary fixed to a short period without investigation on the habituation process and its potential effects on the further responses.

\subsection{Restraint test (back test)}

\subsubsection{Short background}

The back test was used exclusively on piglets and could be named also tonic immobility test (as similar with the tonic immobility test done in poultry). In its original form the back test was done to characterize the fear responses or strategies of the animals rather than the level of fear per se [77], however it has since been compared with other traditional fear tests $[74,70]$. The back test was carried out in two different ways, either by placing the animal in a cradle and then immobilizing it by placing a light weight on its chest $[81,78]$, or by simply placing the animal on its back on a flat surface, a table or the floor, and then pressing gently but firmly on its chest and hind legs $[82,74,66]$.

\subsubsection{Repeatability}

When repeated tests were carried out the time span varied between few days and one to 4 weeks. Repeatability for the test was either not found $[74,66]$, was low $(<0.40 ;[68,83])$ or high [82]. The discrepancy in results may be attributed to the time span between subsequent tests, shorter when high correlations were found. 


\subsubsection{Validity}

The back test for pigs has a varied record with some scientists reporting correlations between the back test and other fear tests related to human approach test [68], tests of aggression [82]. Relationships were also reported between the subpopulations defined on the back test responses and physiological parameters [77], production parameters (lean meat percentagecarcass grading; [83]).

For some authors, this test appears very arbitrary, superficial and has no theoretical justification in terms of motivational and functional basis $[74,84]$. For instance authors are not convinced that such test can be considered as a non social test, one of the few normal situation in which a young pig would be found on its back being during a staged encounter. In addition the extrapolation of coping theory from the back test appears critical when intra and inter-situation consistency were low and the bimodal distribution was failed.

\subsubsection{Conclusion}

The results from studies suggest that the fear response should be evaluated through the TI duration. Nevertheless when associated with other tests, the order to apply the test can change the interpretation of the results. For instance the response to tonic immobility test performed after an emergence test can be regarded rather than reflecting a learned aversiveness or fear more reflecting an element of activity [17]. Data on the validity of the test are conflicting and inconclusive. Some studies provide support for subpopulations interpreted as proactive and reactive coping pattern $[82,77,17,81]$. The use of backtest as a valuable tool to be implemented by farmers for the formation of groups was suggested [66], nevertheless results remains inconclusive and their interpretations of results ambiguous depending in what the tests actually measure in the form they have applied.

\subsection{Handling tests}

\subsubsection{Short background}

In all cases handling tests involve human presence and consequently combine the potential stressful trait of the procedure of handling and the fear towards human. The animals were handled either as a group or tested individually. Various procedures were used in the handling tests including especially husbandry practice such as the transit of the animals, the weighting or the restraining nose used for veterinary inspection [76]. In handling test the variables most commonly recorded concerns the ease of transit and the responsiveness to restraint both expressed as scores including motor reactivity and vocalizations.

\subsubsection{Repeatability - validity}

Repeatability over time was not directly evaluated in the studies testing husbandry practice. Nevertheless consistent responses in different handling tests in group or individual situation were observed in female pig [76]. On the other hand, animals with high responsiveness to handling (resistance to handling) tend to show greater attention to a novel object but without longer contact with it. This suggests that the novel object may also be perceived as aversive by high responders. In return no correlation was found between handling tests and social challenge test (Group feeding competition).

\subsubsection{Conclusion}

The responsiveness to handling in group situation might be ambiguous. Indeed handling effects can be confounded with the effects of social facilitation which may lead to overestimation of the handling effect itself. Pigs in group situation might also have competed to leave the home pen or to move in a corridor, according to the hierarchy pressure and the social cohesiveness within group. The human involvement in the handling procedures need to pay attention on the interaction between the confidence levels of tested animals towards the handler and the responsiveness to handling itself. According to the experience with human, the interaction with the handler might become either rewarding by a pleasurable experience which would exclude fear or additional stressor by aversive experience which would strengthen the handling effect [85].

\subsection{Others tests}

\subsubsection{Light/Dark - emergency test}

3.5.1.1. Short background. The design Light/Dark test is a modification of the apparatus use for mice [86] and consists of two box, illuminated and dark, connected by an opened door. Time spent in the brightly lit compartment was firstly considered as a valid measure of aversion of light as shown in rodents [11]. Nevertheless the anxiolytic effect of diazepam in the $\mathrm{L} / \mathrm{D}$ has not been reported as did in rodents [70] and time spent in the lit compartment appears more related to activity than fear of novelty [69].

In the emergency test, the design consist of a start box connected by a door to a test arena [14] and measure the reluctance to enter an arena from a start box, usually the home pen or a cage. This test is usually associated with the Novel Arena Test and belongs to the group of "timidity" test used in rats or mice [21]. It is expected that the more hesitant an individual is, the more reluctance it will be to enter the arena. This challenge situation should be different if the animal was physically placed into an unfamiliar environment (forced exploration) compared to situation given the opportunity to move around freely between a familiar and a novel environment (voluntary exploration, [87]).

3.5.1.2. Repeatability - validity. Investigations on the L/D test are limited and were carried out once time at 8 weeks of age and so without evaluation of its repeatability [69,70]. Nevertheless significant correlations have been found with others tests carried out before (EPM at 6 weeks, NAT at 7 weeks) but appeared low in both cases $(\mathrm{rs}<0.35)$. No correlation was shown with the tonic immobility tested at 2.5 weeks. In the emergency test, high consistency appeared between the four replicates, done on four consecutive days, except for the first 2 days (rs $>0.50 ;$ [81]). A significant but mall correlation ( $r s=0.37$ ) was found between the first emergency test and the tonic immobility performed thereafter. 
3.5.1.3. Conclusion. By contrast to rodents domestic pigs seems to not perceive the bright light as aversive [70]. Although wild pig are nocturnal with peak of activity at dusk and dawn $[88,89]$, there is very little documentation of preference for a dark area [90]. Domestic pig should be adapted to the strong light in their production environment and consequently may not perceive bright light as aversive [69]. Indeed [85] reported that darkness frightens the piglets whereas the animals have a tendency to move towards a more brightly illuminated area. On the other hand pigs raised in totally enclosed and dimly illuminated windowless pen were observed to balk and refuse to walk into bright sunlight [91]. Finally The Dark/Light test appears to be of less biological relevance for pigs, potentially controlled by the previous lighting environment before the test and thus cannot be relevant as a general fear test.

The interpretation of the emergency test is also conflicting. Indeed it depends to a large extent on the nature of the start box and of the arena which should reflect different fear-evoking situation: relatively safety if start box is the home pen but potential dangerous (unfamiliar and social isolation) if start box is novel for the animal. In the last case the arena is the only way out the box and therefore out of the dangerous. In addition, the consistency over time for tests carried on a short period can be explained by the effect of the experience on the animal's behavior, including the aversiveness of being handled immediately after having entered the arena the previous days and the learning to anticipate this aversiveness.

\subsubsection{Elevated-plus maze test}

3.5.2.1. Short background. The design is a modification of the apparatus commonly used as behavioral models of fear in rodents $[92,93]$ adjusted to the size of young pigs $(6-7$ weeks, $[69,70])$. It consists of two open arms and two enclosed arms opposite each other. The walls of the enclosed arms were made of transparent plexiglas. The maze is elevated $1 \mathrm{~m}$ above the floor and placed in a room without other stimuli. The pigs are placed individually into the centre of the maze facing one of the closed arms and the measured parameters for a period of $5 \mathrm{~min}$ are the number of entries into open arms, the number of entries into closed arms and the time spent on open arms.

An anxiolytic effect of diazepam are found to reduce the avoidance of open arms indicated by an increase in the percent of entries into open arms and the percent of time spent on open arms. This response was related to anxiety whereas the number of entries into closed arms unaffected by the diazepam treatment was related to activity [69]. On the other hand the response level in the EPM test indicated that pigs did not show unconditioned avoidance of open arms relative to closed arms as shown in mice, suggesting that the subtype of anxiety measured in mice and pigs may not be directly synonymous [94].

3.5.2.2. Repeatability, validity. Investigations on the elevatedplus maze test responses of pigs are limited and did not evaluated the test repeatability over time [69], Low significant correlations were found between the number of entries into open arms and the responses to the Dark/light test $(\mathrm{rs}<0.30)$, the tonic immobility ( $\mathrm{rs}=-0.27$ ), and in the Open-Field Test ( $\mathrm{rs}=$ 0.33 ). A study showed no relationships between the activity in the open arms in the EMP test and factors prior to tests, including the age of pigs varied between 33 and 54 days, or the duration of transport between the home pen and the area test [95]. Furthermore a blood sampling followed by transport compared to a "mere" transport before the EPM test did not affect the plus-maze behavior of the pigs tested [95], nor did handling affect the behavior of the pigs [96].

3.5.2.3. Conclusion. The number of entries and the time spent on open arm was interpreted as the purest measures of fear novelty or avoidance, while the time spent in the lit compartment was more related to activity [70]. The EPM test provides a stimuli gradient (aversive, open area, elevated, secure) and appears a way to separate fear and activity-related element [69]. The validity of the test remains unclear though the measures appeared robust to the effects of procedure prior the test or the age of animals. Before any conclusive statement on the hypothesis that anxiety is the major emotional state measured in the EPM test, further investigation are needed with more detailed ethological observations, and repeated and over long period testing, as pointed out by [94].

\section{Fear tests in sheep and goats}

The novel arena test is without doubt the most commonly used fear test for sheep and goats, but both novel object and handling tests are also frequently used. As for the others species the novel object tests are both carried out with the object being present from the start of the trial (e.g. [97]), but also with the object suddenly appearing to the animal (e.g. $[98,99]$. There is an extensive literature on fear tests in sheep, especially for the novel arena test.

\subsection{Novel arena test}

\subsubsection{Background}

The variables most commonly recorded are similar to those for other species: locomotor activity (number of squares entered, standing, walking), rearing, exploration (sniffing) eliminative behavior and vocalizations. One measure which is being used in sheep and goats, but not for other species is latency to feed. There is however a very large difference in the number of variables used with e.g. [100] recording 26 variables whereas [101] only recorded three variables.

The arenas used vary in size, but many studies use one that is approximately $4 \times 4 \mathrm{~m}$. As with the size the time spent in the arena varies, but is often approximately $5 \mathrm{~min}$. The overall level of standardization in most tests is greater than that found for e.g. pigs.

\subsubsection{Repeatability}

Many of the results from the novel arena studies are consistent over time, especially locomotion, vocalizations and defecation/urination [102,104]. The delays used in these studies are in the order of a few weeks. 


\subsubsection{Validity}

There are good physiological as well as behavioral indications that the novel arena test induces fear (e.g. [105]). For sheep, as for all the other species the reaction of the animals to the novel arena test is a mixture of the reaction to the physical situation itself, and social isolation. The strong reaction of sheep to isolation in their home pens makes it probable that a large part of the reactions observed in the novel arena tests are caused by the social isolation rather than the new environment [101,110]. As for other species it seems that it is the number of vocalizations that is most affected by the presence/absence of conspecifics (e.g. [108]).

\subsubsection{Conclusion}

Because of the large number of studies and the relatively good correlations found for other tests the novel arena test can be considered as a good fear test for sheep and goats, which include a social isolation component.

\subsection{Novel object test}

The novel object test is used much less frequently than is e.g. the novel arena test. Of special interest is a number of articles in which it is the manner of appearance of the object that is investigated (e.g. [27,98,109,41]). While it is not uncommon for novel objects to drop down in the novel arena tests for both cattle and pigs, no comparable systematic investigations have been done for these species to study the effect of the appearance, as opposed to the presence, of a novel object.

\subsubsection{Repeatability}

We have not found any studies on the repeatability of the test.

\subsubsection{Validity}

One study [27] found a good correlation to a surprise test and to the exposure to a stationary human. A higher reaction to a novel than a familiar object (heart rate and orienting response), and for the rapidly presented novel object a startle response with a transient increase in heart rate has also been found [98].

\subsubsection{Conclusion}

There has been little research on the reactions to novel object but these responses tend to correlate with the reactions of the animals to other putatively fear-inducing situations.

\subsection{Restraint and human fear tests}

As can be expected there is a huge variation in the performance of these tests. What they all have in common is the presence of a human, either as a stationary or moving object [111] or as someone who actively restraints the animal [105]. When the animal is tested with a human the animals have often been habituated to the arena beforehand for anything from 3 days (e.g. [111]) to up to 10 days [27].

In a number of tests it is not the fear reaction of the animal to the human that is noted but rather the reduction of fear caused by another individual, albeit of another species (e.g. [101,112]).

\subsubsection{Repeatability}

There is a good repeatability of the measures in these tests (e.g. $[111,107,113])$. The variables that show the highest degree of repeatability are similar to those in the novel arena tests i.e. locomotion and vocalizations.

\subsubsection{Validity}

There are correlations between tests with a human present and surprise tests, isolation tests and [27,41,109]. As expected handling decreases the heart rate increase, and decreases the flight distance [6].

\subsubsection{Conclusion}

There are studies showing both good repeatability and validation of the restraint and handling tests. However since there is a large difference in the way they have been done, it is hard to say that restraint and handling tests for sheep and goats have been validated overall.

\section{Fear tests in hens and quail}

The two most common fear tests for poultry are the tonic immobility test (a specialized restraint test) and the novel arena test. Much less frequent are the novel object test and the human approach tests, as well as the emergence test. For poultry a number of related tests, primarily designed to measure sociality have been used, these have not been included in the present review however. Generally speaking the fear tests in poultry are well validated [115], only the most relevant papers published on the fear tests in poultry are therefore presented in the tables.

\subsection{Novel arena test}

\subsubsection{Background}

There is a general consensus that what is tested in the open field is both the general fear of the bird but that there is also a strong effect of social isolation/dependence. The discussion focuses on the degree to which the different variables measure social dependency and general fear/antipredator responses (e.g. [116]).

These different findings make it do indicate that there are two different motivational states that influence the behavior of the birds. This means that e.g. a low number of escape attempts might either be because the birds are very afraid or because they have a low social reinstatement motivation. There are some behaviors that seem to be more heavily influenced by fear than by the social motivation, e.g. the duration of freezing, and ambulation [117].

As for the tonic immobility test the effect of an observer is disputed. While one study [116] found an effect of observer present on latency to distress call, ambulation, as well as fewer lines crossed and fewer escape attempts, another failed to do so [118]. The presence of a new coat however did affect the chickens; the conclusion of the study is that it is the overall novelty of the situation that determines the response of the birds [118].

Steps and areas entered are both good measures of ambulation and have been shown to be closely correlated [119]. 
Table 3

Restraint and handling test in cattle

\begin{tabular}{|c|c|c|c|c|c|c|c|c|}
\hline \multirow[t]{3}{*}{ Reference } & \multirow[t]{3}{*}{$\begin{array}{l}\text { Types of } \\
\text { restraint }\end{array}$} & \multirow[t]{3}{*}{$\begin{array}{l}\text { Time } \\
(\mathrm{Min})\end{array}$} & \multirow{2}{*}{$\begin{array}{l}\begin{array}{l}\text { Age } \\
\text { (week) }\end{array} \\
\text { Sex }\end{array}$} & \multirow{2}{*}{$\begin{array}{l}\begin{array}{l}\text { Replicate, } \mathrm{n} \\
\text { Interval/test }\end{array} \\
\text { - Within }\end{array}$} & \multirow[t]{3}{*}{ Variables } & \multicolumn{2}{|l|}{ Validity } & \multirow[t]{3}{*}{$\begin{array}{l}\text { Procedures and other } \\
\text { factors }\end{array}$} \\
\hline & & & & & & \multirow{2}{*}{$\begin{array}{l}\text { Internal } \\
\text { validity }\end{array}$} & \multirow{2}{*}{$\begin{array}{l}\text { External } \\
\text { validity }\end{array}$} & \\
\hline & & & Breed & - Between & & & & \\
\hline \multirow[t]{3}{*}[47]{} & $\begin{array}{l}\text { Capture, leading, } \\
\text { tethering }\end{array}$ & $\begin{array}{l}\text { No time } \\
\text { given }\end{array}$ & 15 months & & Lat: Time to capture & & $\begin{array}{l}\text { No relationships } \\
\text { between RT and } \\
\text { other tests }\end{array}$ & 3 levels of handling \\
\hline & & & $\mathrm{F}$ & & $\begin{array}{l}\text { Dur: moving: relaxed, } \\
\text { struggling, immobile: } \\
\text { rope stretched/not } \\
\text { stretched/ pulling }\end{array}$ & & & PCA \\
\hline & & & Friesian & & $\begin{array}{l}\text { Other: Ease of leading }(1-5) \text {, } \\
\text { Cortisol levels, heart rate }\end{array}$ & & & $\begin{array}{l}\text { Other tests: NAT, } \\
\text { VAT, FAT }\end{array}$ \\
\hline \multirow[t]{3}{*}{ [49] } & $\begin{array}{l}\text { Separating, } \\
\text { following, } \\
\text { restraining }\end{array}$ & 3 & 3.5 months & 4 rep & $\begin{array}{l}\text { Time need to restrain } \\
\text { or separate the animal }\end{array}$ & & $\begin{array}{l}\text { No relationship } \\
\text { between tests }\end{array}$ & Other tests: NAT \\
\hline & & & $?$ & & & & & \\
\hline & & & Aubrac & & & & & \\
\hline \multirow[t]{2}{*}[50]{} & Tethered & 10 & Heifers & 3 rep & $\begin{array}{l}\text { Duration moving } \\
\text { head or legs, rope } \\
\text { stretched }\end{array}$ & & $\begin{array}{l}\text { Lack of inter- } \\
\text { correlations } \\
\text { between tests }\end{array}$ & PCA analysis \\
\hline & & & $\begin{array}{l}\mathrm{F} \\
\text { Friesian }\end{array}$ & 13 weeks & & & & \\
\hline \multirow[t]{3}{*}[44]{} & $\begin{array}{l}\text { Restrain } \\
\text { in a crush }\end{array}$ & 2 & $\begin{array}{l}6- \\
8 \text { months }\end{array}$ & 3 rep & Movement (score 1-7) & & & $\begin{array}{l}\text { NAT, RT, VAT, FAT } \\
\text { startle, lateralisation, } \\
\text { flight time, ease of sorting, } \\
\text { following; PCA analysis }\end{array}$ \\
\hline & $\begin{array}{l}\text { Restrain } \\
\text { with rope }\end{array}$ & 1.5 & M, Steers & 3,4 weeks & $\begin{array}{l}\text { Time need to restrain } \\
\text { and separate the animals }\end{array}$ & & & \\
\hline & & & Angus & & & & & \\
\hline
\end{tabular}

Abbreviations: Lat. = latency, Dur. = duration, No. = number, Corr. = correlation, PCA $=$ principal component analysis.

Abbreviations for the tests: NAT $=$ novel arena test, NOT $=$ novel object test, RT $=$ Restraint test, VAT $=$ voluntary approach test, FAT $=$ forced approach test.

Chicks tested singly were not affected by the presence of lines, tested in pairs were [119].

\subsubsection{Repeatability}

There is a strong genetic component to the open field behavior, ranging from 0.2 for flying to 0.5 for ambulation [133]. As for the tonic immobility a QTL has been identified that is closely related to the responses in the open field, although the exact QTL seems to be different for adult animals compared to young ones [134].

\subsubsection{Validity}

High novelty in the test arena gives longer latency to movement and lower activity and fewer vocalizations [120]. Electrical shock prior to the testing suppresses distress calling, walking and jumping [116], see also [117]. Birds from enriched environments showed shorter latencies for vocalizations and were more active [125]. Birds that are tested individually showed higher levels of activity, vocalization and defecation (and corticosterone), but longer latency to ambulate, preened and pecked less [121].

\subsubsection{Conclusion}

The open field test is a well validated test. However, what is tested is a combination of two motivations, fear and social reinstatement. This means that the test is less easy to interpret than other fear tests for poultry, especially since isolation per se might cause fear. Tentatively it can be said that it is the latency to move and number of steps that are most indicative of fear whereas the number of peeps and jumps seem to be more related to the social reinstatement.

\subsection{Novel object test}

\subsubsection{Background}

The novel object test is often used to test the level of fearfulness of hens in cages, in that the novel object can be placed in front of the cage and the reaction of the bird or birds noted. This makes this a very practical test for testing large number of birds when these are kept in cages [135-137].

\subsubsection{Repeatability}

The degree of aversion shown in a novel object test is repeatable between days [38] and weeks [124].

\subsubsection{Validity}

Birds from an enriched environment approach the novel object more readily [125], but there is no effect of handling on the response of the birds.

Birds from cages on top tiers are generally found to have greater avoidance of a novel object [136,137]. The same birds 
also showed longer TI ([135,136], but see [137]), and slower approach to a novel object or a human when tested in a pen.

\subsubsection{Conclusion}

The novel object test is a fast and practical fear test. It seems not to be sensitive to handling of the birds and so is possibly a better measure for general fearfulness than is the TI test.

\subsection{Restraint test - tonic immobility}

\subsubsection{Background}

The rationale for the tonic immobility test is that the experimenter simulates a predator thereby eliciting an antipredator response - "death feigning". The idea is that the prey animal plays dead to be able to escape when/if the predator relaxes its concentration. Indeed [141] showed that "death feigning" birds often took advantage of escape opportunities. Later Thompson et al. [142] showed that TI in quail reduced the probability of the birds being predated by cats.
In a systematic study [143] six different positions/materials were tested for inducing TI: table, table with head hanging, cloth and cloth with head hanging, cradle and cradle with cloth. The results show that the number of inductions necessary to induce TI is lowest for the cradle. There was no effect of the cloth on the number of inductions, or on the duration of the TI or latency of first movement. Today most studies on adult hens use a cradle, whereas studies on chicks typically use cloth on e.g. a table top. The bird is restrained for $15 \mathrm{~s}$ with one hand on the sternum and one on the head. They are then released, the variables observed are typically the number of inductions necessary to obtain at least $10 \mathrm{~s}$ of TI, latency to first head movement and time until righting (commonly called the duration of the TI) [144].

There are contradictory findings as regards the presence of an observer and the direction of the gaze of the observer. One study [145] found an effect of the presence of the experimenter, and also found a strong effect of the direction of the gaze (direct vs. averted), another study [146] on the other hand, found that

Table 4

Novel arena test on pigs

\begin{tabular}{|c|c|c|c|c|c|c|c|c|}
\hline \multirow[t]{3}{*}{ Reference } & \multirow{3}{*}{$\begin{array}{l}\text { Arena } \\
\text { size }(\mathrm{m})\end{array}$} & \multirow{3}{*}{$\begin{array}{l}\text { Time } \\
(\min )\end{array}$} & \multirow{2}{*}{$\frac{\text { Age }}{\text { Sex }}$} & \multirow{3}{*}{$\begin{array}{l}\text { Interval } \\
\text { between } \\
\text { tests }\end{array}$} & \multirow[t]{3}{*}{ Variables } & \multicolumn{2}{|l|}{ Validity } & \multirow{3}{*}{$\begin{array}{l}\text { Procedures and other } \\
\text { factors }\end{array}$} \\
\hline & & & & & & Internal & External validity & \\
\hline & & & Breed & & & validity & & \\
\hline \multirow[t]{3}{*}{ [64] } & \multirow[t]{3}{*}{$3 \times 7$} & \multirow[t]{3}{*}{10} & 10 weeks & \multirow[t]{3}{*}{$\begin{array}{l}18 \text { weeks, } \\
2 \text { rep }\end{array}$} & $\begin{array}{l}\text { Lat: start box } \\
\text { emergence }\end{array}$ & \multirow[t]{3}{*}{$\begin{array}{l}\text { Corr test1-test } \\
2 \text { (vocaliz.) }\end{array}$} & \multirow[t]{2}{*}{$\begin{array}{l}\text { Corr locomotion, vocalization } \\
\text { - adrenal reactivity }\end{array}$} & Individual transport, \\
\hline & & & Castrated males & & $\begin{array}{l}\text { No: sections entered } \\
\text { vocalization, defecation }\end{array}$ & & & $\begin{array}{l}\text { ACTH challenge } \\
(24 \text { weeks })\end{array}$ \\
\hline & & & German LW & & & & & \\
\hline \multirow[t]{2}{*}[67]{} & \multirow[t]{2}{*}{$2.4 \times 3.4$} & \multirow[t]{2}{*}{10} & 3 weeks & & $\begin{array}{l}\text { No: vocalization, } \\
\text { locomotion, exploration, } \\
\text { defecations }\end{array}$ & & No corr with aggression test & $\begin{array}{l}\text { Combined tests: } \\
\text { NAT, NOT1, NOT2. }\end{array}$ \\
\hline & & & $\begin{array}{l}\mathrm{F}, \mathrm{M} \\
\mathrm{H} \times(\mathrm{Y} \times \mathrm{Ld})\end{array}$ & & & & & Other test: aggression test \\
\hline \multirow[t]{3}{*}[65]{} & \multirow[t]{3}{*}{$4.4 \times 5.6$} & \multirow[t]{3}{*}{5} & $4-4.5$ months & & Lat: posture & & $\begin{array}{l}\text { Low corr with VAT/ FAT } \\
\text { and aggression test }\end{array}$ & $\begin{array}{l}\text { Combined tests NAT/ } \\
\text { NOT1/RT/ VAT/ NOT2 }\end{array}$ \\
\hline & & & $\mathrm{F}$ & & Dur: posture & & & $\begin{array}{l}\text { Other tests: combined } \\
\text { VAT/FAT; aggression test }\end{array}$ \\
\hline & & & $\mathrm{Ld} \times \mathrm{Y}$ & & $\begin{array}{l}\text { No: posture, } \\
\text { crossed squares }\end{array}$ & & & \\
\hline \multirow[t]{2}{*}[69]{} & \multirow[t]{2}{*}{$\varnothing: 3$} & \multirow[t]{2}{*}{5} & 8 weeks & & $\begin{array}{l}\text { No: lines crossed, entries } \\
\text { within centre, defecations }\end{array}$ & & Low corr with variables of & $\begin{array}{l}\text { Other tests: TI, Elevated } \\
\text { plus maze, Light/Dark test }\end{array}$ \\
\hline & & & $\begin{array}{l}\mathrm{F}, \text { Castrated } \\
\text { males } \\
\mathrm{Ld} \times \mathrm{Y}\end{array}$ & & & & $\begin{array}{l}\text { Elevated plus maze, } \\
\text { Light/Dark } \\
\text { no corr IT }\end{array}$ & \\
\hline \multirow[t]{2}{*}[70]{} & \multirow[t]{2}{*}{$\varnothing: 3$} & \multirow[t]{2}{*}{5} & 8 weeks & & $\begin{array}{l}\text { No: crossed lines, entries } \\
\text { within centre, defecations }\end{array}$ & & $\begin{array}{l}\text { No effect of diazepam on } \\
\text { entries to center and } \\
\text { lines crossed }\end{array}$ & Diazepam treatment \\
\hline & & & $\begin{array}{l}\mathrm{F}, \text { Castrated } \\
\text { males } \\
\mathrm{Ld} \times \mathrm{Y}\end{array}$ & & & & & $\begin{array}{l}\text { Other test: Elevated-plus } \\
\text { maze, Light/Dark test }\end{array}$ \\
\hline \multirow[t]{3}{*}[66]{} & \multirow[t]{3}{*}{$7 \times 1$} & \multirow[t]{3}{*}{10} & 10 weeks & $\begin{array}{l}14 \text { weeks, } \\
2 \text { rep }\end{array}$ & No: locomotion & & No corr with TI & Test arena: corridor \\
\hline & & & & & & & & Combined test: NAT/VAT \\
\hline & & & $\mathrm{GY} \times(\mathrm{GY} \times \mathrm{DLd})$ & & & & & $\begin{array}{l}\text { Others test: TI } \\
\text { Animals tested in group }\end{array}$ \\
\hline
\end{tabular}

Abbreviations: Lat. $=$ latency, Dur. $=$ duration, No. $=$ number Corr. $=$ correlation, $\mathrm{PCA}=$ principal component analysis.

Abbreviations for the tests: NAT $=$ novel arena test, NOT $=$ novel object test, RT $=$ restraint test, TI $=$ tonic immobility, VAT $=$ voluntary approach test, FAT $=$ forced approach test. 
Table 5

Novel object test in pigs

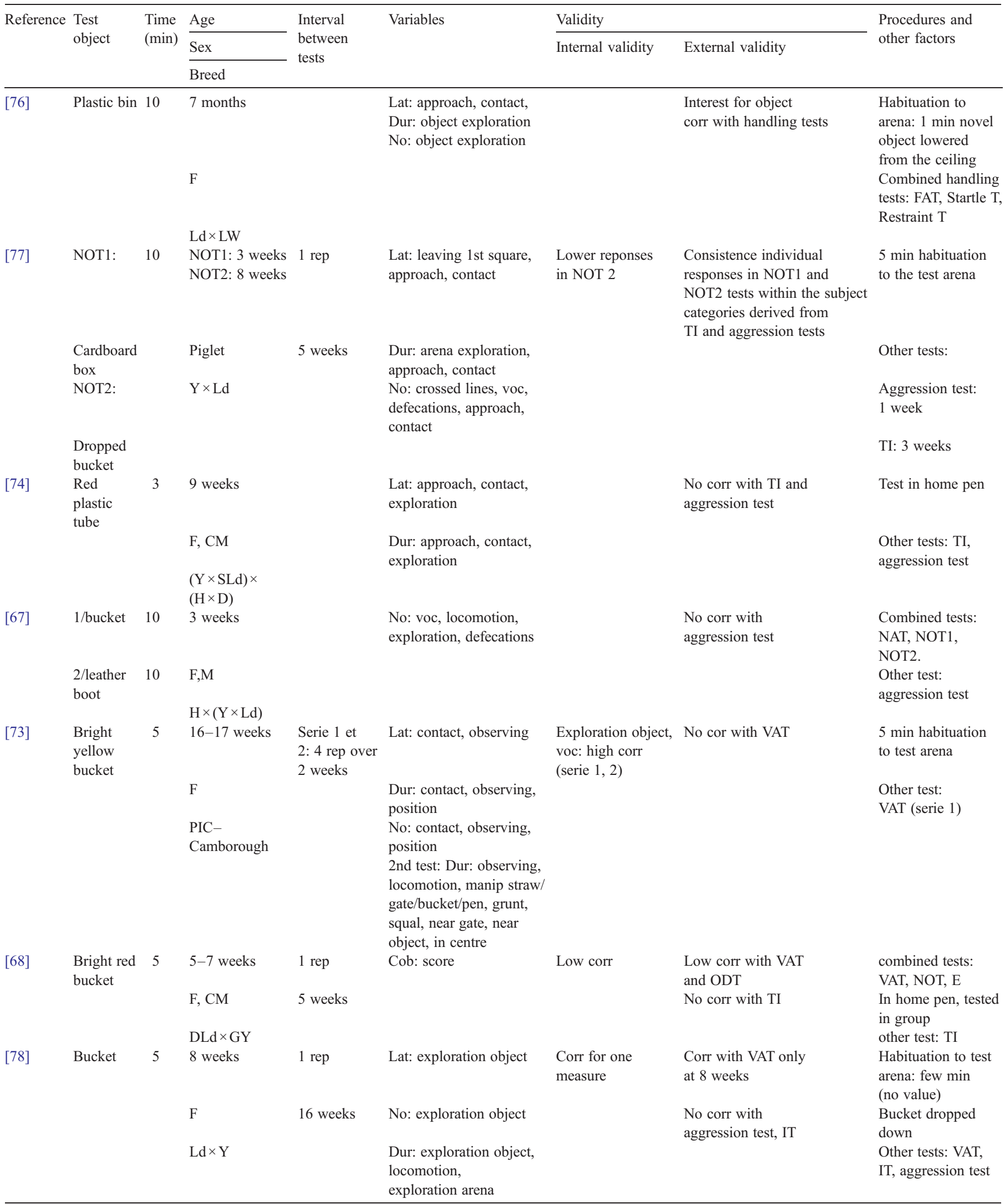

Abbreviations: Lat. $=$ latency, Dur. $=$ duration, No. $=$ number Corr. $=$ correlation, $\mathrm{PCA}=$ principal component analysis.

Abbreviations for the tests: $\mathrm{NAT}=$ novel arena test, $\mathrm{NOT}=$ novel object test, $\mathrm{RT}=$ restraint test, $\mathrm{TI}=$ tonic immobility, $\mathrm{VAT}=$ voluntary approach test, $\mathrm{FAT}=$ forced approach test. 
neither spectacles/sunglasses nor the presence/absence of the experimenter affected the TI in adult Isa Brown hens.

In most cases the tonic immobility test is performed on an animal that is isolated from its conspecifics. Under some circumstances it might however be desirable to test the animals in group. One study [147] tested the effect of the presence on conspecifics, in groups of 15, 30, 60 and 120 individuals. The TI duration was almost four times shorter when tested with the group present than when the animals were tested in isolation. The same response pattern emerged however. When only one

Table 6

Restraint test in pigs

\begin{tabular}{|c|c|c|c|c|c|c|c|c|}
\hline \multirow[t]{3}{*}{ Reference } & \multirow{3}{*}{$\begin{array}{l}\text { Type of } \\
\text { test }\end{array}$} & \multirow[t]{3}{*}{ Time } & \multirow{3}{*}{$\frac{\frac{\text { Age }}{\text { Sex }}}{\text { Breed }}$} & \multirow{3}{*}{$\begin{array}{l}\text { Interval } \\
\text { between } \\
\text { tests }\end{array}$} & \multirow[t]{3}{*}{ Variables } & \multicolumn{2}{|l|}{ Validity } & \multirow{3}{*}{$\begin{array}{l}\text { Procedures and other } \\
\text { factors }\end{array}$} \\
\hline & & & & & & Internal & External validity & \\
\hline & & & & & & validity & & \\
\hline \multirow[t]{3}{*}[82]{} & $\begin{array}{l}\text { Backtest } \\
\text { (manual } \\
\text { restraint) }\end{array}$ & $60 \mathrm{~s}$ & $1-3$ weeks & 5 rep & Lat: escape attempts & High & $\begin{array}{l}\text { High with } \\
\text { aggression test }\end{array}$ & $\begin{array}{l}\text { Other test : } \\
\text { aggression test }\end{array}$ \\
\hline & & & $\mathrm{F}, \mathrm{M}$ & $2-3$ days & $\begin{array}{l}\text { No: escape attempts, } \\
\text { voc }\end{array}$ & & & \\
\hline & & & $\mathrm{Y} \times \mathrm{DLd}$ & & & & & \\
\hline \multirow[t]{2}{*}[77]{} & $\begin{array}{l}\text { Backtest } \\
\text { (manual } \\
\text { restraint) }\end{array}$ & $60 \mathrm{~s}$ & 1 week & 5 rep & No: escape attempts & & $\begin{array}{l}\text { High with } \\
\text { aggression test, }\end{array}$ & $\begin{array}{l}\text { Other test : } \\
\text { aggression test, NOT }\end{array}$ \\
\hline & & & $\begin{array}{l}\mathrm{F}, \mathrm{M} \\
\mathrm{Y} \times \mathrm{DLd}\end{array}$ & $2-3$ days & & & High with NOT & \\
\hline \multirow[t]{2}{*}[74]{} & $\begin{array}{l}\text { Backtest } \\
\text { (manual } \\
\text { restraint) }\end{array}$ & $60 \mathrm{~s}$ & 1 week & 4 rep & $\begin{array}{l}\text { No: escape attempts, } \\
\text { voc. }\end{array}$ & Low & $\begin{array}{l}\text { No corr with AS } \\
\text { and NOT }\end{array}$ & Test in home pen \\
\hline & & & $\mathrm{F}$ & 1 week & & & & $\begin{array}{l}\text { Other test: NOT, } \\
\text { aggression test }\end{array}$ \\
\hline \multirow[t]{3}{*}[68]{} & $\begin{array}{l}\text { Backtest } \\
\text { (manual } \\
\text { restraint) }\end{array}$ & $60 \mathrm{~s}$ & $\begin{array}{l}\mathrm{Y} \times \mathrm{SLd} \times \mathrm{H} \times \mathrm{D} \\
3 \text { or } 10 \text { days }\end{array}$ & 1 rep: 7 days & No: escape attempts & Low & $\begin{array}{l}\text { High corr with some } \\
\text { production parameters }\end{array}$ & $\begin{array}{l}\text { Measures on } \\
\text { production } \\
\text { parameters }\end{array}$ \\
\hline & & & $\mathrm{F}, \mathrm{C}$ & & & & & \\
\hline & & & $\mathrm{DLd} \times \mathrm{GY}$ & & & & & \\
\hline \multirow[t]{3}{*}[66]{} & $\begin{array}{l}\text { Backtest } \\
\text { (manual } \\
\text { restraint) }\end{array}$ & $60 \mathrm{~s}$ & $2-4$ days & 1 rep & Dur: escape attempts & & No corr with NAT/VAT & $\begin{array}{l}\text { Other test: combined } \\
\text { NAT/VAT }\end{array}$ \\
\hline & & & $\mathrm{F}$ & 4 weeks & $\begin{array}{l}\text { No: escape attempts, } \\
\text { voc }\end{array}$ & & & \\
\hline & & & $\mathrm{GY} \times(\mathrm{GY} \times \mathrm{DLd})$ & & & & & \\
\hline \multirow[t]{2}{*}[68]{} & $\begin{array}{l}\text { Backtest } \\
\text { (manual } \\
\text { restraint) }\end{array}$ & $60 \mathrm{~s}$ & 3 days & 2 rep & No: escape attempts & Low & $\begin{array}{l}\text { Corr with VAT and } \\
\text { NOT, only at } 7 \mathrm{~d}\end{array}$ & $\begin{array}{l}\text { Combined tests: VAT, } \\
\text { NOT, Emergence } \\
\text { in home pen }\end{array}$ \\
\hline & & & $\begin{array}{l}\mathrm{F}, \mathrm{C} \\
\mathrm{DLd} \times \mathrm{GY}\end{array}$ & $7-20$ days & & & & \\
\hline \multirow[t]{2}{*}[81]{} & $\begin{array}{l}\text { Backtest } \\
\text { (weight) }\end{array}$ & $5 \min \max$ & 2.5 weeks & no rep & Dur: immobility & & Corr with RT and NAT & Other tests: RT, NAT \\
\hline & & & $\mathrm{F}, \mathrm{B}$ & & No: inductions & & & \\
\hline \multirow[t]{2}{*}{ [17] } & $\begin{array}{l}\text { Backtest } \\
\text { (weight) }\end{array}$ & $5 \min \max$ & $\begin{array}{l}\mathrm{LW} \times \mathrm{Ld} ; \mathrm{LW} \\
2.5 \text { weeks }\end{array}$ & 3 rep & Dur: immobility & $\begin{array}{l}\text { High for } \\
\text { duration }\end{array}$ & $\begin{array}{l}\text { Low and limited to } \\
\text { the first Emergence test }\end{array}$ & $\begin{array}{l}\text { Other tests: } \\
\text { Emergence start box }\end{array}$ \\
\hline & & & $\begin{array}{l}\text { F, B } \\
L W \times L d ; L W\end{array}$ & 1 day & No: inductions & & & \\
\hline \multirow[t]{2}{*}{ [70] } & $\begin{array}{l}\text { Backtest } \\
\text { (weight) }\end{array}$ & $5-10 \mathrm{~s}$ & 2.5 weeks & No rep & Dur: immobility & & $\begin{array}{l}\text { Low with } \\
\text { Elevated-plus maze }\end{array}$ & $\begin{array}{l}\text { Other tests: NAT, Light/ } \\
\text { Dark, Elevated-plus maze }\end{array}$ \\
\hline & & & $\mathrm{F}, \mathrm{CM}$ & & No: inductions & & $\begin{array}{l}\text { No with NAT } \\
\text { or Light/Dark }\end{array}$ & \\
\hline \multirow[t]{3}{*}[76]{} & Restraint & $60 \mathrm{~s}$ & 7 months & No rep & $\begin{array}{l}\text { Response score } \\
\text { according to physical } \\
\text { resistance }\end{array}$ & & Corr with Social test & Restraining nose \\
\hline & & & F & & & & & $\begin{array}{l}\text { Combined tests: } \\
\text { FAT, Social test, RT }\end{array}$ \\
\hline & & & $\mathrm{Ld} \times \mathrm{LW}$ & & & & & Other test: NOT \\
\hline
\end{tabular}

Abbreviations: Lat. $=$ latency, Dur. $=$ duration, No. $=$ number, Corr. $=$ correlation, $\mathrm{PCA}=$ principal component analysis.

Abbreviations for the tests: NAT $=$ novel arena test, NOT $=$ novel object test, RT $=$ restraint test, TI $=$ tonic immobility, VAT $=$ voluntary approach test, FAT $=$ forced approach test. 
Novel arena test in sheep and goat

\begin{tabular}{|c|c|c|c|c|c|c|c|c|}
\hline \multirow[t]{3}{*}{ Reference } & \multirow{3}{*}{$\begin{array}{l}\text { Arena } \\
\text { size }(\mathrm{m})\end{array}$} & \multirow{3}{*}{$\begin{array}{l}\text { Time } \\
(\mathrm{min})\end{array}$} & \multirow{2}{*}{$\frac{\text { Age (week) }}{\text { Sex }}$} & \multirow[t]{3}{*}{ Replicate Interval } & \multirow[t]{3}{*}{ Variables } & \multicolumn{2}{|l|}{ Validity } & \multirow[t]{3}{*}{ Procedures and other factors } \\
\hline & & & & & & Internal validity & External validity & \\
\hline & & & Breed & & & & & \\
\hline \multirow[t]{3}{*}{ [102] } & $\begin{array}{l}\text { Circular } \\
\varnothing 6\end{array}$ & 1.5 & Adult & 2 rep: & $\begin{array}{l}\text { No: section entered, urinations, } \\
\text { defecations, vocalizations, } \\
\text { investigations and } \\
\text { foot-stampings }\end{array}$ & $\begin{array}{l}\text { High repeatability for } \\
\text { ambulation, investigation, } \\
\text { voc. and urination }\end{array}$ & & $\begin{array}{l}\text { Exposure to a dog } \\
\text { (following the arena test) }\end{array}$ \\
\hline & & & $\mathrm{F}$ & - 3 weeks & $\begin{array}{l}\text { Other: Subjective score } \\
\text { of emotion }\end{array}$ & $\begin{array}{l}\text { Low for foot-stamping } \\
\text { and emotion }\end{array}$ & & \\
\hline & & & $\begin{array}{l}\text { Crossbred: Cheviot, } \\
\text { or Dorset, or Finnsheep, } \\
\text { or Romney } \times \text { Suffolk- } \\
\text { or } \times \text { Columbia }\end{array}$ & -6 weeks & & & & \\
\hline \multirow[t]{3}{*}{ [103] } & $3.3 \times 4$ & 10 & $\begin{array}{l}1,5,9,14,21,35,49 \\
\text { and } 63 \text { days }\end{array}$ & & Lat: first movement, & $\begin{array}{l}\text { Reduction of voc. and lat. } \\
\text { first movement, } \\
\text { increased movement }\end{array}$ & $\begin{array}{l}\text { Comparable activation of cortic. } \\
\text { with restraint test }\end{array}$ & White noise \\
\hline & & & $\mathrm{M} / \mathrm{F}$ & & No: sections entered & & & Lambs carried by hand \\
\hline & & & Mixed-breed & & $\begin{array}{l}\text { Dur: movement, voc. } \\
\text { Other: plasma cortic levels }\end{array}$ & & & \\
\hline \multirow[t]{3}{*}{ [101] } & $\begin{array}{l}1.3 \times 2 \\
\text { (truck) }\end{array}$ & 5 & 2.5 months & $\begin{array}{l}1 \text { rep } \\
\text { (delay unknown) }\end{array}$ & No: rearings, vocalization & & Home pen vs arena: & $\begin{array}{l}\text { Comparison between sheep } \\
\text { and goat }\end{array}$ \\
\hline & & & M & & Dur: rearings & & - Voc. no different & $\begin{array}{l}\text { Comparison between home } \\
\text { pen and truck }\end{array}$ \\
\hline & & & $\begin{array}{l}\text { Dorset (sheep) Alpine, } \\
\text { Saanen, Toggenburg } \\
\text { and LaMancha (goat) }\end{array}$ & & & & $\begin{array}{l}\text { - More and longer rearings } \\
\text { in the arena test }\end{array}$ & $\begin{array}{l}\text { Comparison between presence } \\
\text { and absence of human }\end{array}$ \\
\hline \multirow[t]{3}{*}{ [97] } & $4 \times 4$ & 5 & 14 and 42 days & 1 rep 4 weeks & Lat: first movement & $\begin{array}{l}\text { Diff in latency, movement, } \\
\text { voc. but none for cortisol }\end{array}$ & & $\begin{array}{l}\text { Reared isolated, in pair or in flock. } \\
\text { Exposure to a novel object } \\
\text { (following the arena test) }\end{array}$ \\
\hline & & & M & & No: sections entered & & & \\
\hline & & & Finnish-Landrace & & $\begin{array}{l}\text { Dur: movement, vocalizations } \\
\text { Other: cortisol }\end{array}$ & & & \\
\hline [104] & $4.4 \times 4$ & 4 & Adult (53 and 58 weeks) & 1 rep 5 weeks & Lat: enter, & $\begin{array}{l}\text { Good correlations for } \\
\text { section entered, sniffings, }\end{array}$ & Some correlations between items & \\
\hline
\end{tabular}

No: section entered, sniffings, voc., defecations

Other: cortisol, vasopressin prolactin, oxytocin

Lat: Vocalisation,

section entered

No: defecations

Dur: movement, eating

Other: cortisol and prolactin
First 30 min: cortisol response to Comparison with restraint isolation is higher than after restraint test (Latin square) After: no difference

No behavioural difference between Possibility of eating

"mirror" and "no mirror" conditions

Cortisol response to isolation higher Test with and without mirror

in "no mirror condition" 


\begin{tabular}{|c|c|c|c|c|c|c|c|c|}
\hline \multirow[t]{3}{*}{ Reference } & \multirow{3}{*}{$\begin{array}{l}\text { Arena } \\
\text { size }(\mathrm{m})\end{array}$} & \multirow{3}{*}{$\begin{array}{l}\text { Time } \\
(\mathrm{min})\end{array}$} & \multirow{2}{*}{$\begin{array}{l}\text { Age (week) } \\
\text { Sex }\end{array}$} & \multirow[t]{3}{*}{ Replicate Interval } & \multirow[t]{3}{*}{ Variables } & \multicolumn{2}{|l|}{ Validity } & \multirow[t]{3}{*}{ Procedures and other factors } \\
\hline & & & & & & Internal validity & External validity & \\
\hline & & & Breed & & & & & \\
\hline \multirow[t]{3}{*}{ [27] } & $10 \times 10$ & 4 & $5-22$ months & & Lat: to enter, to feed, first voc & & $\begin{array}{l}\text { Corr with surprise test and } \\
\text { exposure to a stationary human }\end{array}$ & $\begin{array}{l}\text { 10-day period of habituation } \\
\text { (i.e., free access with partners } \\
\text { and food). No definition of } \\
\text { most of the variables. }\end{array}$ \\
\hline & & & $\mathrm{M} / \mathrm{F}$ & & $\begin{array}{l}\text { No: voc. defecations, escape } \\
\text { attempts, squares entered, trots }\end{array}$ & & & 3 other tests: \\
\hline & & & $\begin{array}{l}\text { Ile-de-France and } \\
\text { Romano v }\end{array}$ & & Dur: feeding, immobile & & & surprise, human and novel object \\
\hline \multirow[t]{4}{*}{ [107] } & $4 \times 6$ & $\begin{array}{l}4 \times 3 \\
\text { times }\end{array}$ & 12 months & 3 steps: & $\begin{array}{l}\text { No: sections entered, sniffings, } \\
\text { voc, defecations, } \\
\text { urinations, rearings }\end{array}$ & $\begin{array}{l}\text { Corr between sections } \\
\text { entered and voc. }\end{array}$ & Presence of food: & 2 other tests: \\
\hline & & & $\mathrm{F}$ & 1. alone & & & decrease in sections entered and voc & Human stationary \\
\hline & & & $\begin{array}{l}\text { Mérinos d'Arles, } \\
\text { Romano v, } \mathrm{M} \times \mathrm{R} \\
\text { and } \mathrm{R} \times \mathrm{M}\end{array}$ & 2. with food & & & $\begin{array}{l}\text { Presence of pen-mates: decrease in } \\
\text { sections entered and } \\
\text { urination/defecation }\end{array}$ & Human and pen-mates \\
\hline & & & & 3. with pen-mates & & & & Comparison between genotypes \\
\hline \multirow[t]{3}{*}{ [41] } & $4 \times 4$ & 4 & Adult & & 22 items & & $\begin{array}{l}\text { Males or testosterone treated } \\
\text { castrated males or females are } \\
\text { less fearful than castrated males } \\
\text { or females }\end{array}$ & $\begin{array}{l}\text { 4-day period of habituation } \\
\text { (i.e., free access with partners } \\
\text { and food) }\end{array}$ \\
\hline & & & $\mathrm{M} / \mathrm{F}$ & & Lat: to enter, feeding & & & \\
\hline & & & $\begin{array}{l}\text { Romano v and } \\
\text { Ile-de-France }\end{array}$ & & Dur: feeding & & & \\
\hline \multirow[t]{3}{*}{ [100] } & $4 \times 4$ & 4 & Adult & & 22 items & & $\begin{array}{l}\text { Reduction of fear reactions of } \\
\text { isolated ewes in the presence } \\
\text { of a sheep picture }\end{array}$ & $\begin{array}{l}\text { 4-day period of habituation } \\
\text { (i.e., free access with partners } \\
\text { and food) }\end{array}$ \\
\hline & & & $\mathrm{F}$ & & Lat: to enter, feeding & & & $\begin{array}{l}3 \text { visual pictures (partner, } \\
\text { human and traffic cone) }\end{array}$ \\
\hline & & & Romano v & & Dur: feeding & & & \\
\hline \multirow[t]{2}{*}{ [108] } & $\begin{array}{l}1.2 \times 1.2 \\
\mathrm{MS}\end{array}$ & 5 & 20-22 days & Either alone & No: voc & $\begin{array}{l}\text { Isolated lambs bleat more } \\
\text { than when paired with a } \\
\text { social partner }\end{array}$ & & $\begin{array}{l}\text { A conspecific image of own vs. } \\
\text { different breed }\end{array}$ \\
\hline & & & & $\begin{array}{l}\text { Or with a partner } \\
\text { (twin or non-twin) } \\
\text { social }\end{array}$ & & $\begin{array}{l}\text { Paired unfamiliar lambs } \\
\text { bleat more than paired } \\
\text { twin lambs }\end{array}$ & & \\
\hline \multirow[t]{3}{*}{ [109] } & $4 \times 4$ & 4 & Adult & & 15 items & & $\begin{array}{l}\text { Corr with surprise test and } \\
\text { exposure to a sitting human }\end{array}$ & $\begin{array}{l}\text { 2-day period of habituation } \\
\text { (i.e., free access with partners } \\
\text { and food) }\end{array}$ \\
\hline & & & $48 \mathrm{M} / 155 \mathrm{~F}$ & & Lat: to enter, feeding & & & \\
\hline & & & France-de-France & & Dur: feeding & & & \\
\hline \multirow[t]{3}{*}{ [99] } & $4.5 \times 4.5$ & 2 & Adult (18 months) & & $\begin{array}{l}\text { No: section entered, } \\
\text { rearings, voc }\end{array}$ & & & $\begin{array}{l}\text { Comparison between prenatal } \\
\text { undernutrition and control }\end{array}$ \\
\hline & & & $\mathrm{M} / \mathrm{F}$ & & & & & 2 other tests: NOT, surprise \\
\hline & & & Scottish Blackface & & & & & \\
\hline
\end{tabular}


Table 8

Handling and restraint tests in sheep and goats

\begin{tabular}{|c|c|c|c|c|c|c|c|c|}
\hline \multirow[t]{3}{*}{ Reference } & \multirow[t]{3}{*}{ Test } & \multirow{3}{*}{$\begin{array}{l}\text { Time } \\
\text { (Min) }\end{array}$} & \multirow{2}{*}{$\begin{array}{l}\text { Age (week) } \\
\text { Sex }\end{array}$} & \multirow{3}{*}{$\begin{array}{l}\text { Interval } \\
\text { between tests }\end{array}$} & \multirow[t]{3}{*}{ Variables } & \multicolumn{2}{|l|}{ Validity } & \multirow[t]{3}{*}{ Procedures and other factors } \\
\hline & & & & & & Internal validity & External validity & \\
\hline & & & Breed & & & & & \\
\hline \multirow[t]{4}{*}{ [101] } & $\begin{array}{l}1.3 \times 2 \\
\text { (truck) }\end{array}$ & 5 & 2.5 months & $\begin{array}{l}1 \text { rep } \\
\text { (delay } \\
\text { unknown) }\end{array}$ & No: rearings, voc & & $\begin{array}{l}\text { Comparison between presence } \\
\text { and absence of human: }\end{array}$ & Comparison between sheep and goat \\
\hline & $\begin{array}{l}\text { Passive } \\
\text { human }\end{array}$ & & M & & $\begin{array}{l}\text { Dur: rearings, contact } \\
\text { with human }\end{array}$ & & $\begin{array}{l}\text { Reduction of vocalizations and } \\
\text { rearings in presence of a human }\end{array}$ & $\begin{array}{l}\text { Comparison between home pen and } \\
\text { truck (animals reared by pairs: one } \\
\text { animal tested in NAT while the other } \\
\text { maintained in home pen) }\end{array}$ \\
\hline & & & $\begin{array}{l}\text { Dorset (sheep) Alpine, } \\
\text { Saanen, Toggenburg } \\
\text { and LaMancha (goat) }\end{array}$ & & & & Species comparison: & $\begin{array}{l}\text { Comparison between presence and } \\
\text { absence of human ( } 2 \text { times alone and } \\
2 \text { times in presence of a human) }\end{array}$ \\
\hline & & & & & & & $\begin{array}{l}\text { Goats spend more time in contact } \\
\text { of the human than sheep }\end{array}$ & \\
\hline \multirow[t]{2}{*}{ [112] } & Sta. human & 5 & 14 weeks & & No: voc & & $\begin{array}{l}\text { Reduction of Vocalization in } \\
\text { presence of a human in } \\
\text { human-reared goat }\end{array}$ & $\begin{array}{l}\text { Comparison between human-reared } \\
\text { and dam-reared }\end{array}$ \\
\hline & $1 \times 1 \mathrm{~m}$ & & $\mathrm{M} / \mathrm{F}$ & & Other: HR & & $\begin{array}{l}\text { No difference in HR between } \\
\text { human-reared and dam-reared }\end{array}$ & \\
\hline \multirow[t]{4}{*}{ [111] } & 2 tests: & $\begin{array}{l}10 \text { and } \\
3.5\end{array}$ & $\begin{array}{l}\text { Alpine goat } \\
14 \text { weeks }\end{array}$ & 2 rep: & 1. Stationary human & $\begin{array}{l}\text { Good corr (ranged from } \\
0.36 \text { to } 0.92\end{array}$ & & $\begin{array}{l}\text { Comparison between human-reared } \\
\text { and dam-reared }\end{array}$ \\
\hline & $\begin{array}{l}\text { 1) stat } \\
\text { human } \\
1.8 \times 9.8\end{array}$ & & $\mathrm{~F}$ & - 22 weeks & $\begin{array}{l}\text { Lat: to proximity, } \\
\text { Dur: proximity, avoidance }\end{array}$ & & & $\begin{array}{l}\text { 3-day period of familiarization } \\
\text { to the holding pen }\end{array}$ \\
\hline & $\begin{array}{l}\text { 2) mov } \\
\text { human }\end{array}$ & & Alpine goat & -30 weeks & 2. Moving human & & & \\
\hline & $\varnothing 2 \mathrm{~m}$ & & & & $\begin{array}{l}\text { No: mean flight distance } \\
\text { Other: Cortisol }\end{array}$ & & & \\
\hline \multirow[t]{3}{*}{ [6] } & $\begin{array}{l}\text { Cage } \\
(1.7 \times 0.5)\end{array}$ & & Adult & & $\begin{array}{l}\text { Flight distance test } \\
\text { No: flight distance } \\
\text { Other: HR }\end{array}$ & $\begin{array}{l}\text { Flight distance and HR of } g \\
\text { those of control sheep }\end{array}$ & led sheep are less than & $\begin{array}{l}\text { Effect of five previous } \\
\text { handing (routine) }\end{array}$ \\
\hline & $\begin{array}{l}\text { Human } \\
\text { appr }\end{array}$ & & Wethers & & Aversion test & & & \\
\hline & & & Merino & & Dur: transit time & & & \\
\hline \multirow[t]{3}{*}{ [27] } & $10 \times 10$ & 4 & 5-22 months & & 15 items & & $\begin{array}{l}\text { Corr with surprise test and } \\
\text { exposure to a stationary human }\end{array}$ & $\begin{array}{l}\text { 10-day period of habituation } \\
\text { (i.e., free access with } \\
\text { partners and food) }\end{array}$ \\
\hline & Stat human & & $\mathrm{M} / \mathrm{F}$ & & Lat: to enter, feeding & & & 3 other tests: \\
\hline & & & $\begin{array}{l}\text { Ile-de-France } \\
\text { and Romanov }\end{array}$ & & Dur: feeding & & & surprise, novel arena and object \\
\hline
\end{tabular}


Table 8 (continued)

\begin{tabular}{|c|c|c|c|c|c|c|c|c|}
\hline \multirow[t]{3}{*}{ Reference } & \multirow[t]{3}{*}{ Test } & \multirow{3}{*}{$\begin{array}{l}\text { Time } \\
\text { (Min) }\end{array}$} & \multirow{2}{*}{$\begin{array}{l}\text { Age (week) } \\
\text { Sex }\end{array}$} & \multirow{3}{*}{$\begin{array}{l}\text { Interval } \\
\text { between tests }\end{array}$} & \multirow[t]{3}{*}{ Variables } & \multicolumn{2}{|l|}{ Validity } & \multirow[t]{3}{*}{ Procedures and other factors } \\
\hline & & & & & & Internal validity & External validity & \\
\hline & & & Breed & & & & & \\
\hline \multirow[t]{3}{*}{ [41] } & Stat human & & 8 months & & 24 items & & $\begin{array}{l}\text { Corr. with other fear tests } \\
\text { (isolation, suddenness) }\end{array}$ & $\begin{array}{l}\text { 4-day period of habituation (i.e., free } \\
\text { access with partners and food) }\end{array}$ \\
\hline & & & $\mathrm{M} / \mathrm{F}$ & & Lat: to sniff the hum, to eat & & Sex diff. & \\
\hline & & & Rom and Ile-de-France & & $\begin{array}{l}\text { No: glances at human, } \\
\text { sniffing the human }\end{array}$ & & & \\
\hline \multirow[t]{3}{*}{ [110] } & $4 \times 6$ & $\begin{array}{l}4 \times 2 \\
\text { times }\end{array}$ & 12 months & 2 steps: & $\begin{array}{l}\text { No: section entered, sniffings, } \\
\text { vocalizations, defecations, } \\
\text { urinations, rearings }\end{array}$ & $\begin{array}{l}\text { High corr for section entered, } \\
\text { vocalizations and } \\
\text { eliminations }\end{array}$ & $\begin{array}{l}\text { Corr between section entered } \\
\text { and vocalizations, and between } \\
\text { section entered and eliminations }\end{array}$ & $\begin{array}{l}2 \text { other tests: animal alone, } \\
\text { animal with pen-mates }\end{array}$ \\
\hline & Stat human & & $\mathrm{F}$ & 1. $\mathrm{H}$ stat & & & & Comparison between genotypes \\
\hline & & & $\begin{array}{l}\text { Mérinos d'Arles, } \\
\text { Romanov, } \mathrm{M} \times \mathrm{R} \\
\text { and RxM }\end{array}$ & $\begin{array}{l}\text { 2. H stat } \\
\text { with } \\
\text { pen-mates }\end{array}$ & & & & \\
\hline \multirow[t]{3}{*}{ [113] } & $\begin{array}{l}\text { Stat human } \\
\text { in front of } \\
\text { pen-mates }\end{array}$ & 10 & Adult & 2 rep: & $\begin{array}{l}\text { No: distance to human, } \\
\text { section entered, } \\
\text { voc, elimination }\end{array}$ & $\begin{array}{l}\text { Highly repeatable: } \\
\text { Section entered: } 0.48 \text {, } \\
\text { Vocalisation: } 0.57\end{array}$ & Lines comparison: & $\begin{array}{l}\text { Lines comparison (Trangie fertility } \\
\text { flock vs. random flock) }\end{array}$ \\
\hline & & & $\mathrm{F}$ & $\begin{array}{l}12 \mathrm{~m} \text { after } \\
\text { and } 3 \mathrm{~m} \text { after }\end{array}$ & & & $\begin{array}{l}\text { Fertility flock are closer to human } \\
\text { and move less than random flock }\end{array}$ & \\
\hline & & & $\begin{array}{l}\text { Trangie fertility and } \\
\text { random flocks }\end{array}$ & & & & & \\
\hline \multirow[t]{3}{*}{ [114] } & Stat human & 2 and 4 & $4-10$ weeks & 1 rep: & Lat: contact & $\begin{array}{l}\text { For each type of test, no } \\
\text { change between tests } \\
\text { performed before } \\
\text { and after weaning }\end{array}$ & & $\begin{array}{l}\text { Comparison between human-reared } \\
\text { and dam-reared lambs }\end{array}$ \\
\hline & $\begin{array}{l}\text { 1) in home } \\
\text { pen }\end{array}$ & & $\mathrm{F}$ & $\begin{array}{l}5 \text { weeks } \\
\text { after the } \\
\text { first test } \\
\text { (after } \\
\text { weaning) }\end{array}$ & No: voc, agitation & & & \\
\hline & $\begin{array}{l}\text { 2) in test } \\
\text { pen }\end{array}$ & & INRA401 & & Dur: contact & & & \\
\hline \multirow[t]{3}{*}{ [109] } & $4 \times 4$ & 4 & Adult & & 15 items & & $\begin{array}{l}\text { Corr with isolation test } \\
\text { and surprise test }\end{array}$ & $\begin{array}{l}\text { A sat and immobile human } \\
\text { behind the trough. }\end{array}$ \\
\hline & & & $48 \mathrm{M} / 155 \mathrm{~F}$ & & Lat: to enter, feeding & & & $\begin{array}{l}\text { 2-day period of habituation (i.e., free } \\
\text { access with partners and food) }\end{array}$ \\
\hline & & & Ile-de-France & & Dur: feeding & & & \\
\hline \multirow[t]{3}{*}{ [105] } & $\begin{array}{l}\text { Suspending } \\
\text { in a canvas } \\
\text { sling }\end{array}$ & 120 & Adult & & Other: Cortisol & & $\begin{array}{l}\text { First } 30 \mathrm{~min} \text { : cortisol response } \\
\text { to isolation is higher than } \\
\text { after restraint }\end{array}$ & Restraint test \\
\hline & & & Wethers & & Vasopressin & & After: no difference & $\begin{array}{l}\text { Comparison with isolation } \\
\text { test (Latin square) }\end{array}$ \\
\hline & & & Clun forest & & Prolactin & & & \\
\hline
\end{tabular}

Abbreviations: Lat. $=$ latency, Dur. $=$ duration, No. = number, Corr. = correlation, PCA = principal component analysis.

Abbreviations for the tests: NAT $=$ novel arena test, NOT $=$ novel object test, $\mathrm{RT}=$ restraint test, $\mathrm{TI}=$ tonic immobility, VAT $=$ voluntary approach test, $\mathrm{FAT}=$ forced approach test. 
Table 9

Novel arena test in chickens and quail

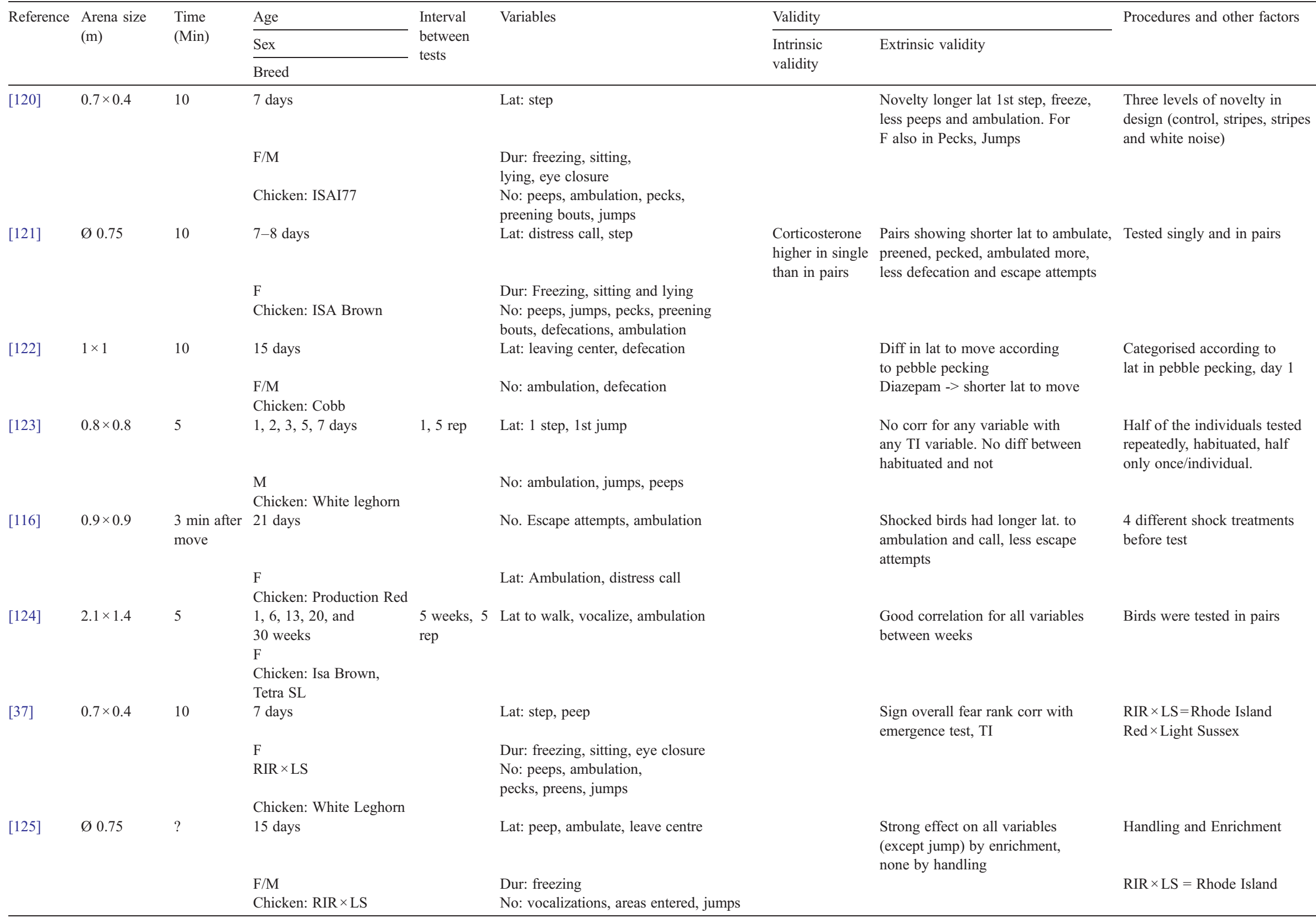




\begin{tabular}{|c|c|c|c|c|c|c|c|c|}
\hline \multirow[t]{3}{*}{ Reference } & \multirow{3}{*}{$\begin{array}{l}\text { Arena size } \\
(\mathrm{m})\end{array}$} & \multirow{3}{*}{$\begin{array}{l}\text { Time } \\
\text { (Min) }\end{array}$} & \multirow{3}{*}{$\frac{\frac{\text { Age }}{\text { Sex }}}{\text { Breed }}$} & \multirow{3}{*}{$\begin{array}{l}\text { Interval } \\
\text { between } \\
\text { tests }\end{array}$} & \multirow[t]{3}{*}{ Variables } & \multicolumn{2}{|l|}{ Validity } & \multirow[t]{3}{*}{ Procedures and other factors } \\
\hline & & & & & & Intrinsic & Extrinsic validity & \\
\hline & & & & & & & & \\
\hline \multirow[t]{3}{*}{ [126] } & $\varnothing 0.9$ & 10 & 25 days & & Lat: vocalization, activity & & $\begin{array}{l}\text { Effect on latency and number } \\
\text { of ambulation. }\end{array}$ & $\begin{array}{l}\text { Anxiogenic drug - } \\
\text { beta-carboline }\end{array}$ \\
\hline & & & $?$ & & No: ambulation, jumps & & & \\
\hline & & & Chicken: Production Red & & & & & \\
\hline \multirow[t]{3}{*}{ [127] } & $\varnothing 1.0$ & 5 & 7 days & & Lat: vocalization, ambulation & & $\begin{array}{l}\text { Difference between strains } \\
\text { (except crouching and defecations) } \\
\text { but no correlation to TI responses }\end{array}$ & $\begin{array}{l}\text { High and low feather pecking } \\
\text { lines }\end{array}$ \\
\hline & & & $\mathrm{F}$ & & Dur: freezing, crouching, & & & \\
\hline & & & Chicken: White Leghorn & & No: vocalization, defecation, ambulation & & & \\
\hline \multirow[t]{3}{*}{ [128] } & $\varnothing 0.9$ & 15 & 25 (Red), $18(\mathrm{WL})$ days & & Lat: vocalization, ambulation & & $\begin{array}{l}\text { Both drugs reduced latencies, and } \\
\text { increased ambulation }\end{array}$ & Scopolamine and atropine \\
\hline & & & $?$ & & No: vocalization, ambulation & & & \\
\hline & & & $\begin{array}{l}\text { Chicken: Red Production } \\
\text { and White Leghorn }\end{array}$ & & & & & \\
\hline \multirow[t]{3}{*}{ [129] } & $0.7 \times 0.4$ & 15 & $6,7,8,9$ days & 1 day & Lat: ambulation & & $\begin{array}{l}\text { Decreases with repeated exposure: } \\
\text { ambulation latency, freezing, sitting, } \\
\text { lying, eye-closing, head-shaking }\end{array}$ & $\begin{array}{l}\text { One strain derived from Shaver } \\
288 \text {, one from Brown Leghorn } \\
\text { and one from Rhode Island } \\
\text { Red } \times \text { Light Sussex }\end{array}$ \\
\hline & & & Chicken: & & $\begin{array}{l}\text { Dur: freezing, standing, sitting, } \\
\text { eyes closed, lying, walking }\end{array}$ & & $\begin{array}{l}\text { Increases: distress calls, ambulation, } \\
\text { walking time, pecking, } \\
\text { preening, jumping }\end{array}$ & \\
\hline & & & 3 strains & & $\begin{array}{l}\text { No: ambulation, defecation, } \\
\text { distress calls, preens, pecks, head-shakes, } \\
\text { wing flaps, jumps, bill openings, scratches }\end{array}$ & & & \\
\hline \multirow[t]{3}{*}{ [130] } & $0.6 \times 0.3 \times 0.4$ & 10 & $8-9$ & & Lat: freezing & & $\begin{array}{l}\text { Agreement with line effects } \\
\text { in other fear tests }\end{array}$ & $\begin{array}{l}\text { Non-selected, high and low } \\
\text { activity lines }\end{array}$ \\
\hline & & & $\mathrm{M} / \mathrm{F}$ & & No: voc., ambulation jumping, pecking & & & \\
\hline & & & Quail & & & & & \\
\hline \multirow[t]{3}{*}{ [39] } & $1.0 \times 0.75$ & & 8 & & No: voc, ambulation & & $\begin{array}{l}\text { Corr with scores in startle, } \\
\text { emergence, TI tests }\end{array}$ & \\
\hline & & & $\mathrm{M} / \mathrm{F}$ & & & & & \\
\hline & & & Quail & & & & & \\
\hline \multirow[t]{4}{*}{ [131] } & $0.8 \times 0.7 \times 0.6$ & 5 & $6-7$ & & Dur: freezing & & $\begin{array}{l}\text { Strong PCA Corr with fear scores } \\
\text { in TI and HIW tests }\end{array}$ & $\begin{array}{l}\text { Short and long tonic } \\
\text { immobility lines }\end{array}$ \\
\hline & & & $\mathrm{M} / \mathrm{F}$ & & No: voc., ambulation jumping, defecation & & Inhibition > in LTI than STI birds & \\
\hline & & & Quail & & & & Env. Enrich reduced inhibition/fear & \\
\hline & & & STI, LTI & & & & & \\
\hline \multirow[t]{4}{*}{ [132] } & $0.8 \times 0.7 \times 0.6$ & 5 & 10 & & Dur: freezing & & $\begin{array}{l}\text { Inhibition more in High stress } \\
\text { than low stress lines }\end{array}$ & Low and high stress lines \\
\hline & & & $\mathrm{M} / \mathrm{F}$ & & No: voc., ambulation & & & \\
\hline & & & Quail & & Jumping & & & \\
\hline & & & LS, HS & & & & & \\
\hline
\end{tabular}

Abbreviations: Lat. $=$ latency, Dur. $=$ duration, No. $=$ number Corr. $=$ correlation, $\mathrm{PCA}=$ principal component analysis.

Abbreviations for the tests: NAT $=$ novel arena test, NOT $=$ novel object test, $\mathrm{RT}=$ restraint test, $\mathrm{TI}=$ tonic immobility, VAT $=$ voluntary approach test, FAT $=$ forced approach test. 
other animal is present the respective relationship of the animals seems to be relevant [148]. Regular handling has a strong effect on the duration of TI (e.g. [149,150]), as does enriched home cages [125].

\subsubsection{Repeatability}

The repeatability of the tonic immobility test is good $[38,124]$. There is also a study that indicates a QTL specific for the tonic immobility response [156], something that also indicates stability in the behavioral response.

\subsubsection{Validity}

There is ample evidence that the duration of the tonic immobility response is a measure of the level of fear. Aversive treatment prior to the induction is known to increase the duration of TI $[152,151]$, whereas regular handling results in a decrease of TI $[149,150]$. Birds from enriched environments also tend to show shorter TI durations [125]. Overall the duration of TI seems to be a more sensitive measure than the number of inductions needed (but see [157]).

There are various reports on the effect of age on tonic immobility. There is some agreement that it is hard, some say impossible, to induce a TI response very early in the life of the chick (e.g. [158]). Later studies have however shown that it is a quantitative rather than qualitative difference, and that while it is easier to induce it later in life (after day 3 ) it is also possible to do so at a very young age [123].

\subsubsection{Conclusion}

The tonic immobility test is a well validated fear test that can be used for both quail and chickens. It works well under a range of conditions, but these need to be standardized if the result is to be valid. Of particular practical importance is that the birds are caught and handled in the same way prior to the test, and that the presence/absence of the experimenter and the direction of the experimenters gaze is standardized.

\subsection{Other tests}

\subsubsection{Emergence test}

There are a number of alternative fear tests that have been used in chickens and in quail. One of these, the emergence test, is based on the logic of the Light/Dark test in rodents [86]. There is little evidence to suggest that light is aversive to poultry (unless it is very bright) and the test can perhaps best be seen as a variety of the novel arena test.

\subsubsection{Validity}

Overall the emergence test is well validated with good correlations to e.g. the novel arena test and TI (e.g. [37,131]).

\subsubsection{Repeatability}

Little is known about the repeatability of the test.

\subsubsection{Conclusion}

The emergence test is well validated, but it is uncertain how much novel information is gained from this test, compared to a novel arena test. The novel arena is better validated and more commonly used and is thus to be preferred.

\section{Fear test in horses}

Novel object, restraint, novel arena, voluntary and forced approach to human are all fear tests used in horses. These tests are usually done one by one, but in some studies combined tests are carried out for example by introducing a novel object into the open field arena after an habituation period within the test arena or by including a novel object or a human in the novel environment right from the start.

\subsection{Novel arena test}

\subsubsection{Background}

This test is sometimes used in horses and the variables most commonly recorded are: locomotor activity (standing, walk, trot, and exploration), eliminatory behavior (defecation, urination) tail position and vocalizations. The arena is usually $30 \times 15 \mathrm{~m}$. the time spent in the arena varies between 5 and $20 \mathrm{~min}$. Horses tested are adult. The open field was usually combined with other tests performed thereafter within the same arena [160-162].

\subsubsection{Repeatability}

There is only a repeated study which used 9 days interval and the results were consistent over the times [160]. The animals are always tested alone.

\subsubsection{Validity}

The behaviour of horses in a novel arena situation does correlate with their behavior in other fear tests at low level ( $\mathrm{rs}=0.305$; [162]) only in males $(r=0.71 ;[161])$ or not at all [160].

\subsubsection{Conclusion}

Open field is not widely used to test fear reaction in horses and for this reason it is difficult to draw clear conclusions due to the discrepancy in the obtained results. However due to the lack of strong correlation with other tests of fear the open field test can not be recommended as a general fear test for horses.

\subsection{Novel object test}

\subsubsection{Background}

The novel object test is sometimes performed after a habituation period to a barren open arena used in some case as a previous open-field test when different tests are combined [160-162].

The novel stimulus tested are usually visual, an object introduced by human on the floor before or after the habituation period within the arena, or dropped from the ceiling and left on the floor [162] or rotating from the ceiling [163]. The visual stimulus varies from a cage which contains a colorful inflated ball [162] to a red plastic child's sledge [160] to a rotation equipment with two balloons [163] or a colored open umbrella [164]. Horses are usually tested alone. Habituation period to the test arena before the confrontation to a novel object varies 
between 0 and $4 \mathrm{~min}$. Animals are tested at very different ages young (till 3-4 years old) and adult from 5 to 17 years old.

The variables most commonly recorded indicated the interest towards the novel stimulus measured by the latency to the contact, distance from the novel object, frequency or duration of contact, exploration, body posture.

\subsubsection{Repeatability}

Studies have used no interval [164] or at very different time intervals, from 9 days [160] to 1 month up to 1 year $[165,166]$. This difference in time interval may explain the differing results on the consistency over time. Whereas one study [160], found no consistency between the behaviors another study in which the tests were carried out over a longer period did find such a consistency [166].

\subsubsection{Validity}

Few correlations have been reported between the response to novel object and others tests, such as handling test. A positive correlation was found between reactivity to novel object, questionnaire about horse temperament and hr frequency during the test [163].

\subsubsection{Conclusion}

Factors such as time (development) and situation (test) may also an important role in the individual's behavioral reaction.

Table 10

Novel object test in chickens and quail

\begin{tabular}{|c|c|c|c|c|c|c|c|c|}
\hline \multirow[t]{4}{*}{ Reference } & \multirow[t]{4}{*}{ Stimulus } & \multirow{4}{*}{$\begin{array}{l}\text { Time } \\
(\mathrm{min})\end{array}$} & \multirow{4}{*}{$\begin{array}{l}\text { Age (day) } \\
\text { Sex } \\
\text { Species: } \\
\text { Breed }\end{array}$} & \multirow{4}{*}{$\begin{array}{l}\text { Interval } \\
\text { between } \\
\text { tests }\end{array}$} & \multirow[t]{4}{*}{ Variables } & \multicolumn{2}{|l|}{ Validity } & \multirow{4}{*}{$\begin{array}{l}\text { Procedures and } \\
\text { other factors }\end{array}$} \\
\hline & & & & & & \multirow{3}{*}{$\begin{array}{l}\text { Intrinsic } \\
\text { validity }\end{array}$} & \multirow[t]{3}{*}{ Extrinsic validity } & \\
\hline & & & & & & & & \\
\hline & & & & & & & & \\
\hline \multirow[t]{3}{*}{ [124] } & $\begin{array}{l}\text { Varying } \\
\text { novel objects }\end{array}$ & 3 & $\begin{array}{l}1,6,13,20, \\
\text { and } 30 \text { weeks }\end{array}$ & $\begin{array}{l}5-10 \\
\text { weeks, } \\
5 \text { rep }\end{array}$ & $\begin{array}{l}\text { Presence in } 4 \\
\text { proximity zones }\end{array}$ & & Good correlation between weeks & $\begin{array}{l}\text { All birds in } \\
\text { each pen tested } \\
\text { in group }\end{array}$ \\
\hline & & & $\mathrm{F}$ & & & & & \\
\hline & & & $\begin{array}{l}\text { Chicken: } \\
\text { Isa Brown, } \\
\text { Tetra SL }\end{array}$ & & & & & \\
\hline \multirow[t]{3}{*}{ [125] } & $\begin{array}{l}\text { Light bulb }+ \\
\text { rosette over } \\
\text { drinker }\end{array}$ & 4 & 13 days & & Lat: approach & & $\begin{array}{l}\text { Strong effect on all variables by } \\
\text { enrichment, none by handling } \\
\text { (except freezing) }\end{array}$ & $\begin{array}{l}\text { Handling and } \\
\text { Enrichment }\end{array}$ \\
\hline & & & $\mathrm{M} / \mathrm{F}$ & & Dur: freezing & & & $\begin{array}{l}\mathrm{RIR} \times \mathrm{LS}= \\
\text { Rhode Island }\end{array}$ \\
\hline & & & $\begin{array}{l}\text { Chicken: } \\
\text { RIR } \times \text { LS }\end{array}$ & & No: pecks, position & & & \\
\hline \multirow[t]{4}{*}{ [138] } & Novel food & $\begin{array}{l}2 \mathrm{~min} \\
15 \mathrm{~min} \\
4 \mathrm{~h}\end{array}$ & 31 weeks & & Lat: head out, feed & & $\begin{array}{l}\text { M showed more avoidance of novel } \\
\text { food and ate less, but more active } \\
\text { behaviour in approach test, no diff in TI }\end{array}$ & $\begin{array}{l}\text { Intact males } \\
\text { and capons }\end{array}$ \\
\hline & & & M/Capons & & Dur: feeding & & & \\
\hline & & & Chicken: & & $\begin{array}{l}\text { No: feeding, pecks, } \\
\text { scrapes, shakes, preening }\end{array}$ & & & \\
\hline & & & Warren SSL & & Amount food eaten & & & \\
\hline \multirow[t]{5}{*}{ [135] } & Rod & 2 & 36 weeks & & Degree of avoidance & & $\begin{array}{l}\text { Top tiers reacted more fearfully, } \\
\text { as in TI, novel object in pen and } \\
\text { human in pen }\end{array}$ & $\begin{array}{l}\text { Housed singly, } \\
\text { tested in home } \\
\text { cage } 45 \times 30 \mathrm{~cm}\end{array}$ \\
\hline & & & $\mathrm{F}$ & & & & & \\
\hline & & & Chicken: & & & & & \\
\hline & & & Golden & & & & & \\
\hline & & & Comet & & & & & \\
\hline \multirow[t]{3}{*}{ [139] } & $\begin{array}{l}\text { Colored } \\
\text { fishing float }\end{array}$ & 3 & 27 & None & Approach/avoidance & & $\begin{array}{l}\text { Avoidance reduced by vitamin } \mathrm{C} \\
\text { (anti-stress) treatment }\end{array}$ & $\begin{array}{l}\text { Scan sampling } \\
\text { of position at } \\
10 \mathrm{~s} \text { intervals. }\end{array}$ \\
\hline & & & $\mathrm{M} / \mathrm{F}$ & & & & & \\
\hline & & & Quail & & & & & \\
\hline \multirow[t]{3}{*}{ [140] } & $\begin{array}{l}\text { Colored } \\
\text { fishing float }\end{array}$ & 3 & 26 & None & Approach/avoidance & & $\begin{array}{l}\text { Agreement with line effects } \\
\text { in TI fear tests }\end{array}$ & $\begin{array}{l}\text { Low and high } \\
\text { body weight lines }\end{array}$ \\
\hline & & & $\mathrm{M} / \mathrm{F}$ & & & & & $\begin{array}{l}\text { Scan sampling of } \\
\text { position at } \\
10 \mathrm{sec} \text { intervals. }\end{array}$ \\
\hline & & & Quail & & & & & \\
\hline
\end{tabular}

Abbreviations: Lat. $=$ latency, Dur. $=$ duration, No. $=$ number, Corr. $=$ correlation, $\mathrm{PCA}=$ principal component analysis.

Abbreviations for the tests: NAT $=$ novel arena test, NOT $=$ novel object test, RT $=$ restraint test, TI $=$ tonic immobility, VAT $=$ voluntary approach test, FAT $=$ forced approach test. 
Table 11

Tonic immobility in chickens and quail

\begin{tabular}{|c|c|c|c|c|c|c|c|c|}
\hline \multirow[t]{3}{*}{ Reference } & \multirow[t]{3}{*}{ Substrate } & \multirow[t]{3}{*}{ Time (Min) } & \multirow{2}{*}{$\begin{array}{l}\text { Age (d) } \\
\text { Sex }\end{array}$} & \multirow{3}{*}{$\begin{array}{l}\text { Interval } \\
\text { between } \\
\text { - tests }\end{array}$} & \multirow[t]{3}{*}{ Variables } & \multicolumn{2}{|l|}{ Validity } & \multirow[t]{3}{*}{ Procedures and other factors } \\
\hline & & & & & & Intrinsic validity & Extrinsic validity & \\
\hline & & & Breed & & & & & \\
\hline \multirow[t]{3}{*}{ [122] } & Table & 30 & 15 & 14 days & No: inductions & & $\begin{array}{l}\text { Difference in lat to move } \\
\text { according to pebble pecking }\end{array}$ & $\begin{array}{l}\text { Categorized according to lat } \\
\text { in pebble pecking, day } 1\end{array}$ \\
\hline & & & $\mathrm{F} / \mathrm{M}$ & & Dur. TI & & $\begin{array}{l}\text { Diazepam affected dur. TI in } \\
\text { high and middle fear groups }\end{array}$ & \\
\hline & & & Chicken: Cobb & & & & & \\
\hline \multirow[t]{3}{*}{ [123] } & Paper & Until recov & $1,2,3,5,7$ & N/A & No: inductions & Corr. within test & $\begin{array}{l}\text { No corr for any variable } \\
\text { with any NAT variable }\end{array}$ & \\
\hline & & & M & & Lat: vocal & & & \\
\hline & & & Chicken: White leghorn & & Dur: TI & & & \\
\hline \multirow[t]{2}{*}{ [151] } & Table & 10 & 10 & N/A & No: inductions & & $\begin{array}{l}\text { Restraint cage prior to TI gave } \\
\text { longer TI duration }\end{array}$ & \\
\hline & & & $\mathrm{F} / \mathrm{M}$ & & Dur. TI & & & \\
\hline \multirow[t]{3}{*}{ [152] } & Cradle & No max given & $\begin{array}{l}\text { Chicken: Cobb } \\
45 \text { (Ross) } 2 \text { years (ISA) }\end{array}$ & N/A & Dur. TI & & $\begin{array}{l}\text { Roughly handled birds } \\
\text { showed longer TI }\end{array}$ & $\begin{array}{l}\text { Carried, upright, upright with } \\
\text { stroking or rough (inverted) }\end{array}$ \\
\hline & & & $?$ (Ross) F (ISA) & & Lat. first head movement & & & \\
\hline & & & Chicken: Ross ISA Brown & & & & & \\
\hline \multirow[t]{2}{*}{ [124] } & Table, cradle & 20 & $1,6,13,20$, and 30 weeks & 5 weeks & Dur. TI & & $\begin{array}{l}\text { Good correlation for all } \\
\text { variables between weeks }\end{array}$ & $\begin{array}{l}\text { Young birds were tested on table, } \\
\text { older in cradle. No TI could be } \\
\text { induced in week } 6\end{array}$ \\
\hline & & & $\mathrm{F}$ & & & & & \\
\hline \multirow[t]{3}{*}{ [37] } & $0.7 \times 0.4$ & 10 & $\begin{array}{l}\text { Chicken: Isa Brown, Tetra SL } \\
7 \text { days }\end{array}$ & & Lat: step, peep & & $\begin{array}{l}\text { Sign overall fear rank corr with } \\
\text { emergence test, NAT }\end{array}$ & $\begin{array}{l}\text { RIR } \times \text { LS }=\text { Rhode Island } \\
\text { Red } \times \text { Light Sussex }\end{array}$ \\
\hline & & & $\mathrm{F}$ & & $\begin{array}{l}\text { Dur: freezing, sitting, } \\
\text { eye closure }\end{array}$ & & & \\
\hline & & & $\begin{array}{l}\text { Chicken: White } \\
\text { Leghorn RIR } \times \text { LS }\end{array}$ & & $\begin{array}{l}\text { No: peeps, ambulation, } \\
\text { pecks, preens, jumps }\end{array}$ & & & \\
\hline [125] & Table & 10 & 20 days & & No: inductions & & $\begin{array}{l}\text { Strong effect on all variables } \\
\text { by enrichment (except inductions), }\end{array}$ & Handling and Enrichment \\
\hline
\end{tabular}

and handling

RIR $\times$ LS $=$ Rhode Island

Lat: vocalize,
head movement
Dur: TI

No: inductions

M showed more active behaviour,

but more avoidance of novel

Intact males and capons

object, no diff in TI

Lat: head movement,

M/Capons

Dur: TI

Chicken: Warren SSL

[150] Table

20

Dur: TI

Handled chicks had shorter TI, also less avoidance

Chicken: ISA Brown 


\begin{tabular}{|c|c|c|c|c|c|c|c|c|}
\hline \multirow[t]{3}{*}{ Reference } & \multirow[t]{3}{*}{ Substrate } & \multirow[t]{3}{*}{ Time (Min) } & \multirow{2}{*}{$\begin{array}{l}\text { Age (d) } \\
\text { Sex }\end{array}$} & \multirow{3}{*}{$\begin{array}{l}\text { Interval } \\
\text { between } \\
\text { tests }\end{array}$} & \multirow[t]{3}{*}{ Variables } & \multicolumn{2}{|l|}{ Validity } & \multirow[t]{3}{*}{ Procedures and other factors } \\
\hline & & & & & & Intrinsic validity & Extrinsic validity & \\
\hline & & & Breed & & & & & \\
\hline \multirow[t]{2}{*}{ [128] } & Table & 30 & $\begin{array}{l}25 \\
?\end{array}$ & & $\begin{array}{l}\text { No: inductions } \\
\text { Dur: TI }\end{array}$ & & No effect of anxiogenic drug & Anxiogenic drug - beta-carboline \\
\hline & & & Chicken: Production Red & & & & & \\
\hline \multirow[t]{3}{*}{ [127] } & Cradle & 15 & 33 & & Lat: vocalization, ambulation & & $\begin{array}{l}\text { No difference in TI responses, } \\
\text { but in open field }\end{array}$ & High and low feather pecking lines \\
\hline & & & $\mathrm{F}$ & & Dur: freezing, crouching, & & & \\
\hline & & & Chicken: White Leghorn & & $\begin{array}{l}\text { No: vocalization, } \\
\text { defecation, ambulation }\end{array}$ & & & \\
\hline \multirow[t]{3}{*}{ [130] } & Tabletop & 10 & 14 & None & Susceptibility & & $\begin{array}{l}\text { Agreement with line effects } \\
\text { in other fear tests }\end{array}$ & High and low activity lines \\
\hline & & & $\mathrm{M} / \mathrm{F}$ & & Head movement & & & \\
\hline & & & Quail & & Duration of TI & & & \\
\hline \multirow[t]{3}{*}{ [39] } & Cradle & 5 & 14 & None & Susceptibility & & $\begin{array}{l}\text { Corr with scores in startle, } \\
\text { emergence, open field tests }\end{array}$ & \\
\hline & & & $\mathrm{M} / \mathrm{F}$ & & Duration of TI & & & \\
\hline & & & Quail & & & & & \\
\hline \multirow[t]{3}{*}{ [131] } & Wooden cradle & 5 & 10 & None & Susceptibility & & Corr with fear scores in NAT & Short and long time TI lines \\
\hline & & & $\mathrm{M} / \mathrm{F}$ & & Duration of TI & & TI reduced by Enrich. or Handling & \\
\hline & & & Quail & & & & & \\
\hline \multirow[t]{3}{*}{ [132] } & Cradle & 10 & 13 & None & Susceptibility & & $\begin{array}{l}\text { TI longer in high-fear High stress } \\
\text { than low-fear Low stress quail }\end{array}$ & Low and high stress lines \\
\hline & & & $\mathrm{M} / \mathrm{F}$ & & Head movement & & & \\
\hline & & & Quail & & Duration of TI & & & \\
\hline \multirow[t]{3}{*}{ [153] } & Cradle & 10 & 21 & None & Susceptibility & & $\begin{array}{l}\text { TI }>\text { in high-fear HS } \\
\text { than low-fear LS }\end{array}$ & Low and high stress lines \\
\hline & & & $\mathrm{M} / \mathrm{F}$ & & Head movement & & quail & $\begin{array}{l}\text { Acute stressor }=\text { echanical } \\
\text { restraint for } 5 \text { min. } \\
\text { (controls remained undisturbed) }\end{array}$ \\
\hline & & & Quail & & Duration of TI & & TI increased after acute stressor & \\
\hline \multirow[t]{3}{*}{ [154] } & Cradle & 20 & $71-75$ & None & Susceptibility & & $\begin{array}{l}\text { Prior exposure to acute restraint } \\
\text { stressor increased TI }\end{array}$ & Short and long time TI lines \\
\hline & & & $\mathrm{M} / \mathrm{F}$ & & Duration of TI & & & \\
\hline & & & Quail & & & & & \\
\hline \multirow[t]{3}{*}{ [139] } & Cradle & 10 & 24 & None & Susceptibility & & $\begin{array}{l}\text { TI reduced by vitamin C } \\
\text { (anti-stressor) treatment }\end{array}$ & \\
\hline & & & $\mathrm{M} / \mathrm{F}$ & & Duration of TI & & & \\
\hline & & & Quail & & & & & \\
\hline \multirow[t]{3}{*}{ [140] } & Cradle & 10 & 29,30 & None & Susceptibility & & $\begin{array}{l}\text { Agreement with line effects in } \\
\text { other fear tests }\end{array}$ & Low and high body weight lines \\
\hline & & & $\mathrm{M} / \mathrm{F}$ & & Duration of TI & & & \\
\hline & & & Quail & & & & & \\
\hline \multirow[t]{3}{*}{ [155] } & Cradle & 10 & 136 & None & Duration of TI & & $\begin{array}{l}\text { TI }>\text { in high-fear HS than } \\
\text { low-fear LS quail }\end{array}$ & Low and high stress lines \\
\hline & & & $\mathrm{M} / \mathrm{F}$ & & & & & \\
\hline & & & Quail & & & & & \\
\hline
\end{tabular}

Abbreviations: Lat. $=$ latency, Dur. $=$ duration, No. $=$ number, Corr. $=$ correlation, $\mathrm{PCA}=$ principal component analysis.

Abbreviations for the tests: NAT $=$ novel arenatest, NOT + novet object fest,$/ \mathrm{RT}=$ restraint test, $\mathrm{TI}=$ tonic immobility, VAT $=$ voluntary approach test, FAT $=$ forced approach test. Forkman, B., Boissy, A., Meunier-Salaün, M.-C., Canali, E., Jones, R.B. (2007). A critical 
Table 12

Emergence test in chickens and quail

\begin{tabular}{|c|c|c|c|c|c|c|c|c|}
\hline \multirow[t]{3}{*}{ Reference } & \multirow[t]{3}{*}{ Box (m) } & \multirow{3}{*}{$\begin{array}{l}\text { Time } \\
(\min )\end{array}$} & \multirow{2}{*}{$\begin{array}{l}\text { Age (day) } \\
\text { Sex }\end{array}$} & \multirow{3}{*}{$\begin{array}{l}\text { Interval } \\
\text { between } \\
\text { tests }\end{array}$} & \multirow[t]{3}{*}{ Variables } & \multicolumn{2}{|l|}{ Validity } & \multirow{3}{*}{$\begin{array}{l}\text { Procedures and other } \\
\text { factors }\end{array}$} \\
\hline & & & & & & Intrinsic & Extrinsic validity & \\
\hline & & & Species: Breed & & & validity & & \\
\hline \multirow[t]{3}{*}{ [37] } & $0.7 \times 0.4$ & 10 & 7 days & & Lat: step, peep & & $\begin{array}{l}\text { Sign overall fear rank } \\
\text { corr with NAT, TI }\end{array}$ & $\begin{array}{l}\text { RIR } \times \text { LS }=\text { Rhode Island } \\
\text { Red } \times \text { Light Sussex }\end{array}$ \\
\hline & & & $\mathrm{F}$ & & $\begin{array}{l}\text { Dur: freezing, } \\
\text { sitting, eye closure }\end{array}$ & & & \\
\hline & & & $\begin{array}{l}\text { Chicken: White } \\
\text { Leghorn RIR } \times \text { LS }\end{array}$ & & $\begin{array}{l}\text { No: peeps, ambulation, } \\
\text { pecks, preens, jumps }\end{array}$ & & & \\
\hline \multirow[t]{5}{*}[125]{} & $30 \times 20 /$ comp & $?$ & 14 days & & $\begin{array}{l}\text { Lat: peep before and } \\
\text { after raising door, head } \\
\text { emergence, full emergence }\end{array}$ & & $\begin{array}{l}\text { Strong effect on all } \\
\text { variables by enrichment, } \\
\text { less by handling }\end{array}$ & H ndling and Enrichment \\
\hline & & & $\mathrm{M} / \mathrm{F}$ & & & & & RIR $\times$ LS $=$ Rhode \\
\hline & & & & & & & & Island $\times$ Light Sussex \\
\hline & & & Chicken: & & & & & 2 min acclim before \\
\hline & & & $\mathrm{RIR} \times \mathrm{LS}$ & & & & & raising door \\
\hline \multirow[t]{3}{*}[130]{} & $0.23 \times 0.23 \times 0.20$ & $2+5$ & $5-6$ & None & Vocalization & & $\begin{array}{l}\text { Agreement with line } \\
\text { effects in other fear tests }\end{array}$ & $\begin{array}{l}\text { Non-selected, high and } \\
\text { low activity lines }\end{array}$ \\
\hline & & & $\mathrm{M} / \mathrm{F}$ & & Head emergence & & & \\
\hline & & & Quail & & Full emergence & & & $\begin{array}{l}\text { Acclimation for } 2 \mathrm{~min} \\
\text { before trapdoor opened }\end{array}$ \\
\hline \multirow[t]{3}{*}[39]{} & $0.24 \times 0.22 \times 0.20$ & $\begin{array}{l}1.66+ \\
3\end{array}$ & 10 & None & Vocalization & & $\begin{array}{l}\text { Corr with scores in } \\
\text { startle, TI, NAT tests }\end{array}$ & $\begin{array}{l}\text { Acclimation for } 100 \mathrm{sec} \\
\text { before trapdoor opened to } \\
\text { allow access to large arena }\end{array}$ \\
\hline & & & $\mathrm{M} / \mathrm{F}$ & & Head emergence & & & \\
\hline & & & Quail & & Full emergence & & & \\
\hline \multirow[t]{3}{*}[131]{} & $0.25 \times 0.22 \times 0.17$ & $1+5$ & $8-9$ & None & Vocalization & & $\begin{array}{l}\text { Strong PCA corr with } \\
\text { NAT and TI scores }\end{array}$ & $\begin{array}{l}\text { Short and long tonic } \\
\text { immobility lines }\end{array}$ \\
\hline & & & $\mathrm{M} / \mathrm{F}$ & & Head emergence & & & $\begin{array}{l}\text { Acclimation for } 2 \mathrm{~min} \\
\text { before trapdoor opened }\end{array}$ \\
\hline & & & Quail & & Full emergence & & $\begin{array}{l}\text { Emergence slower in } \\
\text { high fear long TI birds }\end{array}$ & \\
\hline \multirow[t]{3}{*}[159]{} & $0.21 \times 0.21 \times 0.21$ & $1+10$ & 23 & None & Vocalization, & & $\begin{array}{l}\text { Emergence faster after } \\
\text { vitamin C (anti-stress) } \\
\text { treatment }\end{array}$ & Low and high stress lines \\
\hline & & & $\mathrm{M} / \mathrm{F}$ & & Head emergence & & $\begin{array}{l}\text { Emergence faster in } \\
\text { low-fear low stress than } \\
\text { high-fear high stress quail }\end{array}$ & $\begin{array}{l}\text { Acclimation for } 2 \mathrm{~min} \\
\text { before trapdoor opened }\end{array}$ \\
\hline & & & Quail & & Full emergence & & & \\
\hline
\end{tabular}

Abbreviations: Lat. = latency, Dur. = duration, No. = number, Corr. = correlation, PCA = principal component analysis.

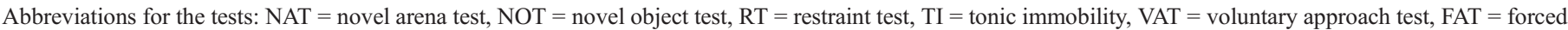
approach test.

Furthermore the nature of the novelty-related stimulus may modulate the responsiveness to novelty.

\subsection{Restraint and human fear tests}

\subsubsection{Background}

In all cases handling tests involve human presence and consequently combine the potential stressful trait of the procedure of handling and the fear towards human. The animals were tested individually. Various procedures were used in the handling tests including husbandry practice such as the transit of the horse on a bridge, or the restraining nose used for veterinary inspection In handling test the variables most commonly recorded concerns the ease, the attempts and time necessary to cross the bridge and the responsiveness to restraint both expressed as scores including motor reactivity and vocalizations and expressions.

\subsubsection{Repeatability - validity}

Repeatability over time was evaluated only in two studies which are contradictory: [166] found a consistency after a year in the responses to cross the bridge while [168] found no consistency. This discrepancy could be due to different kind of handling as in both studies the horses were young.

\subsubsection{Conclusion}

Type of handling and the human involvement in the handling procedures need to pay attention on the interaction between the confidence level of tested animals towards the handler and the responsiveness to handling itself.

\section{Concluding discussion}

Fear is a negative emotion and as such is often included in assessments and recommendations of animal welfare, in e.g. the 
Table 13

Novelty arena test in horses

\begin{tabular}{|c|c|c|c|c|c|c|c|c|}
\hline \multirow[t]{3}{*}{ Reference } & \multirow{3}{*}{$\begin{array}{l}\text { Arena } \\
\text { size } \\
(\mathrm{m})\end{array}$} & \multirow{3}{*}{$\begin{array}{l}\text { Time } \\
\text { (Min) }\end{array}$} & \multirow{3}{*}{$\begin{array}{l}\text { Age (w) } \\
\text { Sex } \\
\text { Breed }\end{array}$} & \multirow{3}{*}{$\begin{array}{l}\text { Replicate, } n \text { Interval/test } \\
\text { - Within } \\
\text { - Between }\end{array}$} & \multirow{3}{*}{ Variables } & \multicolumn{2}{|l|}{ Validity } & \multirow{3}{*}{$\begin{array}{l}\text { Procedures and other } \\
\text { factors }\end{array}$} \\
\hline & & & & & & Internal & External validity & \\
\hline & & & & & & validity & & \\
\hline \multirow[t]{3}{*}{ [160] } & $30 \times 21$ & 20 & $<5-20$ years & 3 & $\begin{array}{l}\text { No: Voc, defecation, } \\
\text { urination }\end{array}$ & $\begin{array}{l}\text { High between } \\
3 \text { repetitions }\end{array}$ & $\begin{array}{l}\text { No correlation between } \\
\text { novel object and OF } \\
\text { or unknown person; no } \\
\text { correlation between } \\
\text { of and startle test }\end{array}$ & PCA, factor analysis \\
\hline & & & $\mathrm{F}$, Gelding & Within: 9 days & $\begin{array}{l}\text { Dur: Stand, Explor, } \\
\text { Sustained walk, Trot, } \\
\text { Vigilance, tail position, } \\
\text { snort, paw }\end{array}$ & & & $\begin{array}{l}\text { Questionnaires, startle } \\
\text { test water spray test }\end{array}$ \\
\hline & & & $\begin{array}{l}\text { TB and } \\
\text { saddle horses }\end{array}$ & & & & & \\
\hline \multirow[t]{2}{*}{ [161] } & $30 \times 15$ & 10 & $1-3$ years & & $\begin{array}{l}\text { Dur: Standing, exploration, } \\
\text { sustained walk, trot, } \\
\text { passage, gallop, vigilance, } \\
\text { tail position, locomotion }\end{array}$ & & $\begin{array}{l}\text { Correlation between } \\
\text { reactivity in O F and } \\
\text { novel object in males }\end{array}$ & $\begin{array}{l}\text { Horses tested in a } \\
\text { familiar arena }\end{array}$ \\
\hline & & & $\begin{array}{l}\text { F,M } \\
\text { French } \\
\text { saddle-breeds } \\
\text { F, M }\end{array}$ & & & & & \\
\hline \multirow[t]{2}{*}{ [162] } & $30 \times 15 f$ & 5 & $3-17$ years & & $\begin{array}{l}\text { Dur: Standing, exploration, } \\
\text { sustained walk, trot, } \\
\text { passage, gallop, vigilance, } \\
\text { tail position, locomotion }\end{array}$ & & $\begin{array}{l}\text { Correlation between } \\
\text { indices in O F and } \\
\text { gregariuousness }\end{array}$ & $\begin{array}{l}\text { Horses tested in a } \\
\text { familiar arena }\end{array}$ \\
\hline & & & $\begin{array}{l}\text { Different } \\
\text { breeds }\end{array}$ & & & & & $\begin{array}{l}\text { Use of indices, ratings } \\
\text { of temperament by } \\
\text { riding teachers }\end{array}$ \\
\hline
\end{tabular}

Abbreviations: Lat. = latency, Dur. = duration, No. = number, Corr. = correlation, PCA = principal component analysis.

Abbreviations for the tests: NAT $=$ novel arena test, NOT $=$ novel object test, RT $=$ restraint test, TI $=$ tonic immobility, VAT $=$ voluntary approach test, FAT $=$ forced approach test.

five freedoms. Despite this, several of the tests commonly used to assess fear in farm animals have not been well validated.

The lack of good fear tests is most acute in cattle and horses, and at present there are no well validate tests for general fear for these species (but see Waiblinger et al. [23] for tests of fear towards humans). For sheep and poultry some of the traditional tests are on the other hand well validated (specifically the arena and the novel object test, and for poultry also the tonic immobility test, although this probably is affected by fear of humans). For pigs finally there exists a wide variety of different tests, these have however relatively low inter-test correlations and cannot be said to be well validated.

The novel arena test, also called open-field test, is a common fear test which has been used for all species in this review. As stated in the introduction it is very probable that different aspects of the arena are the main cause of fear in the different species. So might it e.g. represent a risk of predation for a species evolved to hide in the undergrowth (the jungle fowl/ domestic chicken) whereas it for a species evolved for more open ground (e.g. the horse) might represent something else, e.g. confinement. Using the novel arena test as a fear test for species whose ancestors have evolved for open areas is therefore not recommended.

The high validity for the novel arena test for sheep is somewhat surprising for the reason given above. It might how- ever be that the isolation component is so important for this species that it provokes the fear response [101]. For poultry the novel arena test has a high validity, whereas for pigs the results are conflicting. In the arena tests it is generally the latency to move which is the best validated response for general fear (ref). Vocalizations are more correlated to the isolation component, at least in sheep and poultry $[108,119]$. Locomotion is probably related to curiosity and/or social reinstatement.

The novel object test is an intuitively appealing test. It uses the animal's reaction to a novel stimulus, the novelty of which according to most theories should elicit a fear reaction (e.g. [13]). One of the problems with the test however is the same as for the voluntary approach test in the testing of humanrelationships [23], a non-curious/indifferent animal and a fearful animal will both show a long latency to approach the novel object. In the approach test this can be solved by using a forced approach in which the experimenter moves towards the animal and it is the avoidance reaction of the animal which is measured, however we have not found any corresponding test with a moving novel object.

Restraining an animal can at least in some species be thought to represent a predator attack and as such is an innate fear evoking stimulus. In poultry there are good indications that the freezing seen in the birds is related to an anti-predator response with birds showing a shorter freezing response being more 
Table 14

Novel object and startle test in horse

\begin{tabular}{|c|c|c|c|c|c|c|c|c|}
\hline \multirow[t]{3}{*}{ Reference } & \multirow{3}{*}{$\begin{array}{l}\text { Nature } \\
\text { (test area size, m) }\end{array}$} & \multirow{3}{*}{$\begin{array}{l}\text { Time } \\
\text { (Min) }\end{array}$} & \multirow{2}{*}{$\begin{array}{l}\text { Age (week) } \\
\text { Sex } \\
\end{array}$} & \multirow{2}{*}{$\begin{array}{l}\text { Replicate, } \mathrm{n} \\
\text { Interval/test } \\
\text { - Within } \\
\end{array}$} & \multirow[t]{3}{*}{ Variables } & \multicolumn{2}{|l|}{ Validity } & \multirow[t]{3}{*}{ Procedures and other factors } \\
\hline & & & & & & Internal validity & External validity & \\
\hline & & & Breed & - Between & & & & \\
\hline \multirow[t]{4}{*}{ [164] } & $\begin{array}{l}\text { Indoor Arena } \\
18 \times 21 \mathrm{~m}\end{array}$ & 5 & $5-15$ years & 3 no interval & Lat: time to approach & & $\begin{array}{l}\text { Hr negatively correlated to heads } \\
\text { down and exploring other the n.o. }\end{array}$ & Rating scores of riders \\
\hline & $\begin{array}{l}\text { Open blue and } \\
\text { white umbrella }\end{array}$ & & $\begin{array}{l}\text { Swedish } \\
\text { warmblood } \\
\text { F/Gelding }\end{array}$ & & No: vocalization, locomotion & & $\begin{array}{l}\text { HRV positively correlated } \\
\text { exploring other things }\end{array}$ & PCA \\
\hline & & & & & $\begin{array}{l}\text { Dur: position, posture } \\
\text { of head and tail }\end{array}$ & & $\begin{array}{l}\text { No corr between riders score } \\
\text { and NAT variables }\end{array}$ & \\
\hline & & & & & Other: Heart rate, heart rate variability & & & \\
\hline \multirow[t]{2}{*}{ [165] } & $\begin{array}{l}\text { Indoor Arena } \\
18 \times 21 \mathrm{~m}\end{array}$ & & $\begin{array}{l}9-10 \text { and } 21-22 \\
\text { months F/Gelding }\end{array}$ & 4 & Dur: Physical activity & & $\begin{array}{l}\text { Positive correlation between } \\
\text { with HR negative with HRV }\end{array}$ & \\
\hline & $\begin{array}{l}\text { Open blue and } \\
\text { white umbrella }\end{array}$ & & Dutch warmblood & $\begin{array}{l}1 \text { month } \\
1 \text { year }\end{array}$ & $\begin{array}{l}\text { Other: Heart rate, heart } \\
\text { rate variability }\end{array}$ & & & \\
\hline \multirow[t]{2}{*}{ [166] } & $\begin{array}{l}\text { Indoor Arena } \\
18 \times 21 \mathrm{~m}\end{array}$ & 5 & $\begin{array}{l}9-10 \text { and } 21-22 \\
\text { months } \mathrm{F} / \text { Gelding }\end{array}$ & & Lat: time to approach & Seven in the first year & & $\begin{array}{l}2 \text { minutes isolation } \\
2 \text { minutes in the arena }\end{array}$ \\
\hline & $\begin{array}{l}\text { Open blue and } \\
\text { white umbrella }\end{array}$ & & Dutch warmblood & $\begin{array}{l}1 \text { month } \\
1 \text { year }\end{array}$ & No: vocalization, locomotion & $\begin{array}{l}\text { And } 8 \text { in the second year. } \\
\text { Four out of nine variables } \\
\text { were consistent over the years }\end{array}$ & & PCA \\
\hline [160] & $\begin{array}{l}\text { Bright blue saddle } \\
\text { stand with a red } \\
\text { plastic child's } \\
\text { sledge } \\
1 \times 0.5 \times 1.2\end{array}$ & 10 & $\begin{array}{l}<5-20 \text { years } \\
\text { F/Gelding } \\
\text { TB and saddle } \\
\text { horses }\end{array}$ & $\begin{array}{l}3 \\
\text { within: } \\
9 \text { days }\end{array}$ & $\begin{array}{l}\text { Dur: position, posture of head and tail } \\
\text { No: vocalization, Paw, } \\
\text { defecation, urination, snort, } \\
\text { Dur: Standing, investigation, sustained } \\
\text { walk, trot, vigilance, tail position, }\end{array}$ & No consistent behaviors & $\begin{array}{l}\text { No correlation between novel } \\
\text { object and OF or unknown } \\
\text { person; no correlation between } \\
\text { of and startle test }\end{array}$ & $\begin{array}{l}\text { PCA, Factor analysis } \\
\text { Questionnaires, startle } \\
\text { test water spray test, }\end{array}$ \\
\hline \multirow[t]{3}{*}{ [161] } & & 10 & $1-3$ years & & $\begin{array}{l}\text { Dur: Standing, exploration, } \\
\text { sustained walk, trot, passage, gallop, } \\
\text { vigilance, tail position, locomotion }\end{array}$ & & $\begin{array}{l}\text { Correlation between reactivity in } \\
\mathrm{O} F \text { and novel object in males }\end{array}$ & $\begin{array}{l}\text { Horses tested in a } \\
\text { familiar arena }\end{array}$ \\
\hline & & & $\mathrm{F} / \mathrm{M}$ & & & & $\begin{array}{l}\text { Correlation between time } \\
\text { face unknown object and } \\
\text { time to cross the bridge }\end{array}$ & \\
\hline & & & $\begin{array}{l}\text { French saddle- } \\
\text { breeds }\end{array}$ & & & & & \\
\hline [162] & $\begin{array}{l}\text { cage with a ball } \\
\text { inside } 1 \times 0.8 \times 0.8\end{array}$ & 5 & $3-17$ years & & $\begin{array}{l}\text { Dur: Standing, exploration, sustained } \\
\text { walk, trot, passage, gallop, vigilance, } \\
\text { tail position, locomotion }\end{array}$ & & $\begin{array}{l}\text { Correlation between indices with } \\
\text { novel object and nervousness }\end{array}$ & $\begin{array}{l}\text { Horses tested in a } \\
\text { familiar arena }\end{array}$ \\
\hline \multirow[t]{3}{*}{ [167] } & $\begin{array}{l}\text { Walking and } \\
\text { vocalizing pig }\end{array}$ & & different breeds & No repetition & $\begin{array}{l}\text { No: steps, jumps, head and } \\
\text { neck jerks, flinches, blows and snorts }\end{array}$ & & $\begin{array}{l}\text { No correlation between reactivity } \\
\text { scores and hormone } \\
\text { concentrations }\end{array}$ & $\begin{array}{l}\text { Use of indices, ratings } \\
\text { of temperament by } \\
\text { riding teachers }\end{array}$ \\
\hline & $\begin{array}{l}\text { Popping a balloon } \\
\text { automatic umbrella }\end{array}$ & & F/Gelding & & $\begin{array}{l}\text { Dur: widening of the eyes, } \\
\text { ear positions }\end{array}$ & & $\begin{array}{l}\text { No between temperament score } \\
\text { and average reactivity score }\end{array}$ & $\begin{array}{l}\text { Rating scale to } \\
\text { determine a reactivity scores }\end{array}$ \\
\hline & & & 103 horses? & & Other: cortisol, catecholamines & & & temperament survey \\
\hline
\end{tabular}

Abbreviations: Lat. $=$ latency, Dur. $=$ duration, No. $=$ number Corr. $=$ correlation, $\mathrm{PCA}=$ principal component analysis.

Abbreviations for the tests: NAT $=$ novel arena test, NOT $=$ novel object test, $\mathrm{RT}=$ restraint test, $\mathrm{TI}=$ tonic immobility, $\mathrm{VAT}=$ voluntary approach test, $\mathrm{FAT}=$ forced approach test.

$$
\text { Comment citer ce document }
$$


prone to being killed by predators [142]. The situation in the pig is more complex, in the most common restraint test in the pig, the backtest, the piglet is put on its back and either restrained manually [82] or by means of a small weight [17], and it is hard to see how this situation directly relates to a predation situation. This does not mean that the test is invalid for pigs, it might be that the novelty or strangeness of the situation which might cause a fear response. There is less ecological validity for the response than for poultry however, and the results found are much more varied, ranging from good correlations with other tests [17] to no significant correlations [74].
In most of the studies reported throughout the present review the emphasis is on the sensitivity of a given test. What is tested is if a putative difference in fear levels exists, e.g. if different levels of handling give different results. There has been much less emphasis on the specificity of the test, i.e. whether the correlation between two different tests is caused by a difference in a second factor, e.g. overall activity, rather than a difference in fear (but see e.g. [70]).

In some cases these second factors are welfare irrelevant, as in the example above, but in other cases it is less clear, one of the factors might be the effect of social isolation. As stated in the

Table 15

Restraint and handling tests in horses

\begin{tabular}{|c|c|c|c|c|c|c|c|c|}
\hline \multirow[t]{3}{*}{ Reference } & \multirow{3}{*}{$\begin{array}{l}\text { Nature } \\
\text { area size } \\
(\mathrm{m})\end{array}$} & \multirow[t]{3}{*}{ Time } & \multirow{2}{*}{$\begin{array}{l}\text { Age (week) } \\
\text { Sex }\end{array}$} & \multirow{2}{*}{$\begin{array}{l}\text { Replicate, } \mathrm{n} \\
\text { Interval /test } \\
\text { - Within }\end{array}$} & \multirow[t]{3}{*}{ Variables } & \multicolumn{2}{|l|}{ Validity } & \multirow{3}{*}{$\begin{array}{l}\text { Procedures and } \\
\text { other factors }\end{array}$} \\
\hline & & & & & & Internal validity & External validity & \\
\hline & & & Breed & - Between & & & & \\
\hline \multirow[t]{3}{*}{ [164] } & $\begin{array}{l}\text { Indoor } \\
\text { arena } \\
18 \times 21 \mathrm{~m}\end{array}$ & 12 & $5-15$ years & $\begin{array}{l}3 \text { no } \\
\text { interval }\end{array}$ & Lat: time to approach & & $\begin{array}{l}\text { Heart rate neg. corr. to standing still } \\
\text { in front of the bridge, number of trials } \\
\text { to cross the bridge, and resistance } \\
\text { behaviour in approaching the bridge }\end{array}$ & NOT test \\
\hline & Bridge & & $\begin{array}{l}\text { Swedish } \\
\text { warmblood }\end{array}$ & & No: vocalization & & $\begin{array}{l}\text { Handling test correlated } \\
\text { with riders' scores }\end{array}$ & PCA \\
\hline & & & $\mathrm{F}$, geldings & & $\begin{array}{l}\text { Dur: Locomotion, } \\
\text { position within the arena, } \\
\text { posture of head and tail } \\
\text { Other: heart rate }\end{array}$ & & & Riders scores \\
\hline \multirow[t]{3}{*}{ [166] } & $\begin{array}{l}\text { Indoor } \\
\text { arena } \\
18 \times 21 \mathrm{~m}\end{array}$ & 12 & $\begin{array}{l}9-10 \text { and } \\
21-22 \text { months } \\
\text { FM (G) }\end{array}$ & 4 & Lat: time to approach & $\begin{array}{l}\text { All the variables } \\
\text { positively } \\
\text { correlated over } \\
\text { the years }\end{array}$ & & No test \\
\hline & $\begin{array}{l}\text { bridge } \\
2 \text { m wide } \\
4 \text { long }\end{array}$ & & $\begin{array}{l}\text { Dutch } \\
\text { warmblood }\end{array}$ & $\begin{array}{l}1 \text { month } \\
1 \text { year }\end{array}$ & No: vocalization & & & PCA \\
\hline & & & & & $\begin{array}{l}\text { Dur: locomotion, } \\
\text { position within the arena, } \\
\text { posture of head and tail }\end{array}$ & & & \\
\hline \multirow[t]{3}{*}{ [162] } & $\begin{array}{l}\text { Bridge } \\
2 \text { m wide } \\
4 \text { long }\end{array}$ & 10 & $3-17$ years & & $\begin{array}{l}\text { Dur: time required to } \\
\text { cross the bridge }\end{array}$ & & $\begin{array}{l}\text { The horses that crossed the bridge } \\
\text { were faster in learning and } \\
\text { memorisation tasks, positive } \\
\text { correlation between fearful to cross } \\
\text { the bridge and rating score fearful } \\
\text { when handled or ridden }\end{array}$ & $\begin{array}{l}\text { Horses tested in } \\
\text { a familiar arena }\end{array}$ \\
\hline & & & $\begin{array}{l}\text { Different } \\
\text { breeds }\end{array}$ & & & & & $\begin{array}{l}\text { Use of indices, } \\
\text { ratings of } \\
\text { temperament by } \\
\text { riding teachers }\end{array}$ \\
\hline & & & F G & & & & & \\
\hline \multirow[t]{3}{*}{ [161] } & $\begin{array}{l}\text { Bridge } \\
2 \mathrm{~m} \text { wide } \\
1 \text { long }\end{array}$ & 10 & $1-3$ years & & $\begin{array}{l}\text { Dur: time required to } \\
\text { cross the bridge }\end{array}$ & & No correlation with arena test & $\begin{array}{l}\text { Horses tested in } \\
\text { a familiar arena }\end{array}$ \\
\hline & & & $\mathrm{F}, \mathrm{M}$ & & & & $\begin{array}{l}\text { Correlation between time to } \\
\text { cross the bridge and time face } \\
\text { unknown object }\end{array}$ & \\
\hline & & & $\begin{array}{l}\text { French } \\
\text { saddle-breeds } \\
\text { F, M }\end{array}$ & & & & & \\
\hline
\end{tabular}

Abbreviations: Lat. $=$ latency, Dur. $=$ duration, No. $=$ number, Corr. $=$ correlation, $\mathrm{PCA}=$ principal component analysis.

Abbreviations for the tests: NAT $=$ novel arena test, $\mathrm{NOT}=$ novel object test, $\mathrm{RT}=$ restraint test, $\mathrm{TI}=$ tonic immobility, VAT $=$ voluntary approach test, $\mathrm{FAT}=$ forced approach test. 
introduction in many tests the animal is tested alone, and it is probable that some of the fear response shown is an effect of this social isolation. If the fear test is done to evaluate an aspect of animal welfare then it is only relevant to use the test with isolated animals if the animal is often kept alone, i.e. in a situation in which that specific fear inducing stimulus is present. One example might be e.g. the domestic dog in which separation anxiety is a recurring problem [169]. On the other hand a production animal strain with a high level of social dependency might show a strong fear reaction when tested in isolation. This is however probably not relevant from an animal welfare perspective since the animals in almost all production systems will encounter the fear provoking stimulus when together with other individuals.

In most cases it is recommended that the situation/fear provoking stimulus is as simple as possible. There is an unfortunate tendency to mix tests, or alternatively to use several tests in a rapid succession, this is especially true for tests of pigs and to some extent cattle (it is less common in poultry). In [65] an "open field test" consists of the gilt being put into a pen, left for $5 \mathrm{~min}$, a bucket dropped from the ceiling, after $5 \mathrm{~min}$ three persons enter the pen, the gilt is fixated with a nose sling and blood sample is taken, the gilt is covered with a blanket with one person present in the pen, blanket is removed after $5 \mathrm{~min}$, left alone for $5 \mathrm{~min}$ and a spool is dropped from the ceiling (for further examples see e.g. $[67,76])$. Such procedures can lead to difficulties for the interpretation of result according to the order of the successive tests. Indeed the response measured in the following test may reflect an underlying tendency to bring about more or less quickly when animals faced with a new challenging situation. If the response for each type of test was evaluated it would not only help in the interpretation of the results of study, but also be more valuable in a comparative context.

The basis for the studies in which validation is measured as the correlation between behavior patterns in different tests is that an animal responds to fear evoking stimuli in a consistent manner and that fear is a unitary concept. This might however very well be an oversimplification, for e.g. domestic dogs there are a number of examples of both differing behavior and physiological patterns depending on the fear eliciting response [170], as well as different fears which do not correlate with each other but which are internally consistent $[171,172]$. There is no strong a priori reason for believing that fear is unitary concept, and if different tests yield different fear-rankings the alternative that they might be measuring different aspects of fear or "feartypes" has to be considered. Because of this we would like to emphasise a broad approach to the validation of fear tests, ideally using pharmacological, physiological and behavioral methods.

To conclude, we believe that if more effort is put into the development, and validation of standardized behavioral tests to assess fear in farm animals, then this would strengthen the area of applied ethology. While it is important that different tests are developed we would also like to urge researchers to gather information on factors influencing the outcome of relatively simple and standardized tests, which can then later be used "out of the box". (Tables 3, 4, 5, 6, 7, 8, 9, 10,11, 12,13, 14 and 15).

\section{Acknowledgement}

This review/paper/report is based on the conclusions of COST Action 846 Measuring and monitoring farm animal welfare supported by the EU Commission. The text represents the authors' views and does not necessarily represent a position of the Commission who will not be liable for the use made of such information.

\section{References}

[1] Boissy A. Fear and fearfulness in determining behavior. In: Grandin T, editor. Genetics and the behaviour of domestic animals. San Diego, USA: Academic Press; 1998. p. 67-111.

[2] Dwyer CM. How has the risk of predation shaped the behavioural responses of sheep to fear and distress? Anim Welf 2004;13(3):269-81.

[4] Asheim LJ, Mysterud I. External effects of mitigating measures to reduce large carnivore predation on sheep. J Farm Manage 2005;12(4):206-13.

[5] Wohlt JE, Allyn ME, Zajac PK, Katz LS. Cortisol increases in plasma of Holstein heifer calves from handling and method of electrical dehorning. J Dairy Sci 1994;77(12):3725-9.

[6] Hargreaves AL, Hutson GD. The effect of gentling on heart rate, flight distance and aversion of sheep to a handling procedure. Appl Anim Behav Sci 1990;26(3):243-52.

[7] Price EO. Behavioural aspects of animal domestication. Q Rev Biol 1984;59:1-32

[8] Bouissou MF, Boissy A, Le Neindre P, Veissier I. The social behaviour of cattle. In: Keeling L, Gonyou H, editors. Social behaviour in farm animals. Wallingford, UK: CABI Publishing; 2001. p. 113-45.

[9] Fisher A, Matthews L. The social behaviour of sheep. In: Keeling L, Gonyou H, editors. Social behaviour in farm animals. Wallingford, UK: CABI Publishing; 2001. p. 211-45.

[10] Hemsworth PH, Coleman GJ. Human-livestock interactions. In: Hemsworth PH, Coleman GJ, editors. The stockperson and the productivity and welfare of intensively farmed animals, London; 1998.

[11] Ramos A, Mormède P. Stress and emotionality: a multidimensional and genetic approach. Neurosci Biobehav Rev 1998;22:33-57.

[12] Boissy A, Fisher AD, Bouix J, Hinch GN, Le Neindre P. Genetics of fear in ruminant livestock. Livest Prod Sci 2005;93:23-32.

[13] Gray J. The psychology of fear and stress. Problems in behavioural sciences. Cambridge: Cambridge university press; 1987.

[14] Keeling L, Gonyou H. Social. behaviour. in. farm. animals. Wallingford, UK: CABI Publishing; 2001.

[15] Poindron P, Raksanyi I, Orgeur P, Le Neindre P. Comparaison du comportement maternel en bergerie à la parturition chez des brebis primipares ou multipares de race Romanov, Préalpes du Sud et Ile de. France. Genet Sel Evol 1984;16:503-22.

[16] Boissy A, Terlouw C, Le Neindre P. Presence of cues from stressed conspecifics increases reactivity to aversive events in cattle: evidence for the existence of alarm substances in urine. Physiol Behav 1998;63 (4):489-95.

[17] Erhard HW, Mendl M. Tonic immobility and emergence time in pigs more evidence for behavioural strategies. Appl Anim Behav Sci $1999 ; 61: 227-37$.

[18] von Borrel et al. This volume.

[19] Mormède et al. This volume.

[20] Hall CS. Emotional behaviour in the rat: III The relationship between emotionality and ambulatory activity. J Comp Psychol 1936;22:345-52.

[21] Archer J. Tests for emotionality in rat and mice: a review. Anim Behav 1973;21:205-35.

[22] Ramos A, Berton O, Mormède P, Chaouloff F. A multiple test study of anxiety related behaviours in six inbred rat strains. Behav Brain Res 1997;85:57-69.

[23] Waiblinger S, Boivin S, Pedersen V, Tosi M, Janczak AM, Visser EK, et al. Assessing the human animal relationship in farmed species: a critical review. Appl Anim Behav Sci 2006;101:185-242. 
[24] Murphey RM, Duarte FAM, Penedo MCT. Responses of cattle to humans in open spaces: breed comparisons and approach avoidance relationships. Behav Genet 1981;11(1):37-48.

[25] Boissy et al. This volume.

[26] Shelton M, Wade D. Predatory losses: a serious livestock problem. Ann Ind Today 1979;2:4-9.

[27] Romeyer A, Bouissou MF. Assessment of fear reactions in domestic sheep, and influence of breed and rearing conditions. Appl Anim Behav Sci 1992;34(1 2):93-119.

[28] Boissy A, Bouissou MF. Assessment of individual differences in behavioural reactions of heifers exposed to various fear-eliciting situations. Appl Anim Behav Sci 1995;46:17-31.

[29] Weiss JM. Psychological factors in stress and disease. Sci Am 1972;226: $104-13$.

[30] Muir JL, Pfister HP. Time course of the corticosterone and prolactin response following predictable and unpredictable novelty stress in Rattus norvegicus. Physiol Behav 1987;40:103-7.

[31] Tazi A, Dantzer R, Le Moal M. Prediction and control of food rewards modulate endogenous pain inhibitory systems. Behav Brain Res 1987;23: 197-204.

[32] Spruijt BM, van den Bos R, Pijlman FT. A concept of welfare based on reward evaluating mechanisms in the brain: anticipatory behavior as an indicator for the state of reward systems. Appl Anim Behav Sci 2001;72:145-71.

[33] Martin P, Bateson P. Measuring behaviour, an introductory guide. 2nd ed. New York: Cambridge University Press; 1993. p. 1-222.

[34] Brush FR, Baron S, Froehlich JC, Ison JR, Pellegrino LJ, Phillips DS, et al. Genetic differences in avoidance learning by Rattus norvegicus: escape/ avoidance responding, sensitivity to electric shock, discrimination learning and open-field behavior. J Comp Psychol 1985;99:60-73.

[35] Ley R. Open-field behavior, emotionality during fear conditioning and fearmotivated instrumental performance. Bull Psychon Soc 1975;6:598-600.

[36] Goddard ME, Beilharz RG. A factor analysis of fearfulness in potential guide dogs. Appl Anim Behav Sci 1984;12:253-65.

[37] Jones RB, Mills AD. Estimation of fear in two lines of the domestic chick: correlations between various methods. Behav Processes 1983;8:243-53.

[38] Jones RB. Repeatability of fear ranks among adult laying hens. Appl Anim Behav Sci 1988;19:297-304.

[39] Mills AD, Faure JM. The estimation of fear in domestic quail: correlations between various methods and measures. Biol behav 1986;11:235-43.

[40] Boissy A, Bouissou MF. Effects of androgen treatment on behavioural and physiological responses of heifers to fear-eliciting situations. Horm Behav 1994;28:66-83.

[41] Vandenheede M, Bouissou MF. Sex differences in fear reactions in sheep. Appl Anim Behav Sci 1993;37(1):39-55.

[42] de Passillé AM, Rushen J, Martin F. Interpreting the behaviour of calves in an open field test: a factor analysis. Appl Anim Behav Sci 1995;45:201-13.

[43] Lauber MCY, Hemsworth PH, Barnett HL. The effects of age and experience on behavioural development in dairy calves. Appl Anim Behav Sci 2006;99:41-52.

[44] Kilgour RJ, Melville GJ, Greenwood PL. Individual differences in the reaction of beef cattle to situations involving social isolation, close proximity of humans, restraint and novelty. Appl Anim Behav Sci 2006;99: $21-40$.

[45] Kilgour R. The open field test as an assessment of the temperament of dairy cows. Anim Behav 1975;23:615-24.

[46] Kovalčikováč M, Kovalčik K. Relationships between parameters of open field test of cows and their milk production in loose house. Appl Anim Behav Sci 1982/83;9:121-9.

[47] Boissy A, Bouissou MF. Effects of early handling on heifers' subsequent reactivity to humans and to unfamiliar situations. Appl Anim Behav Sci 1988;20:259-73.

[48] Le Neindre P. Influence of rearing conditions and breed on social behaviour and activity of cattle in novel environments. Appl Anim Behav Sci 1989;23:129-40.

[49] Boivin X, Le Neindre P, Chupin JM, Garel JP, Trillat G. Influence of breed and early management on ease of handling and open field behaviour of cattle. Appl Anim Behav Sci 1992;32:313-23.
[50] Van Reenen CG, Engel B, Ruis Heutinck LFM, Van der Werf JTN, Buist WG, Jones RB, et al. Behavioural reactivity of heifer calves in potentially alarming situations: a multivariate and correlational analysis. Appl Anim Behav Sci 2004;85:11-30.

[51] Van Reenen CG, O’Connell NE, Van der Werf JTN, Korte SM, Hopster H, Jones RB, et al. Responses of calves to acute stress: individual consistency and relations between behavioural and physiological measures. Physiol Behav 2005;8:557-70.

[52] Jensen MB, Vestergaard KS, Krohn CC, Munksgaard L. Effect of single versus group housing and space allowance on responses of calves during open field tests. Appl Anim Behav Sci 1997;54:109-21.

[53] Jensen MB. A note on the effect of isolation during testing and length of previous confinement on locomotor behaviour during open-field test in dairy calves. Appl Anim Behav Sci 2001;70(4):309-15.

[54] Arave CW, Mickelsen CH, Walters JL. Effect of early rearing experience on subsequent behavior and production of Holstein heifers. J Dairy Sci 1985;68:923-9.

[55] Dantzer R, Mormede P, Bluthé RM, Soissons J. The effect of different housing conditions on behavioural and adrenocortical reactions in veal calves. Reprod Nutr Dev 1983;23:501-8.

[56] Dellmeier G, Friend TH, Gbur EE. Comparison of four methods of calf confinement. II. Behavior. J Anim Sci 1985;60:1102-9.

[57] Canali E, Verga M, Montagna M, Baldi A. Social interactions and induced behavioural reactions in milk-fed female calves. Appl Anim Behav Sci 1986;16:207-15.

[58] Redbo I. Relations between oral stereotypies, open field behavior, and pituitary adrenal system in growing dairy cattle. Physiol Behav 1998;64: 273-8.

[59] Munksgaard L, Jensen MB. The use of "open field" tests in the assessment of welfare of cattle. Acta Agricult Scand Suppl 1996;27:82-5.

[61] Dellmeier GR, Friend TH, Gbur EE. Effect of changing housing on open field behaviour of calves. Appl Behav Sci 1990;26:215-30.

[62] Miller CP, Wood Gush DGM, Martin P. The effect of rearing systems on the response of calves to novelty. Biol Behav 1986;II:50-60.

[63] Fraser D. The vocalizations and other behaviour of growing pigs in an 'open field' test. Appl Anim Ethol 1974;1(1):3-16.

[64] von Borell E, Ladewig J. Relationship between behaviour and adrenocortical response pattern in domestic pigs. Appl Anim Behav Sci 1992;34:195-206.

[65] Thodberg K, Jensen KH, Herskin MS. A general reaction pattern across situations in prepubertal gilts. Appl Anim Behav Sci 1999;63:103-19.

[66] Ruis MAW, te Brake JHA, van de Burgwal JA, de Jong IC, Blokhuis HJ, Koolhaas JM. Personalities in female domesticated pigs: behaviouiral and physiological indications. Appl Anim Behav Sci 2000;66:31-47.

[67] Jensen P, Forkman B, Thodberg K, Köster E. Individual variation and consistency in piglet behaviour. Appl Anim Behav Sci 1995;45:43-52.

[68] van Kooij E, Kuijpers AH, Schrama JW, van Eerdenburg FJCM, Schouten WGP, Tielen MJM. Can we predict behaviour in pigs? Searching for consistency in behaviour over time and across situations. Appl Anim Behav Sci 2002;75(4):293-305.

[69] Andersen IL, Færevik G, Bøe KE, Janczak AM, Bakken M. Effects of diazepam on the behaviour of weaned pigs in three putative models of anxiety. Appl Anim Behav Sci 2000;68:121-30.

[70] Andersen IL, Bøe KE, Færevik G, Janczak AM, Bakken M. Behavioural evaluation of methods for assessing fear responses in weaned pigs. Appl Anim Behav Sci 2000;69:227-40.

[71] Giroux S, Martineau GP, Robert S. Relationships between individual behavioural traits and post-weaning growth in segregated early-weaned piglets. Appl Anim Behav Sci 2000;70(1):41-8.

[72] Geverink NA, Kappers A, Burgwal van de JA, Lambooij E, Blokhuis HJ, Wiegant VM. Effects of regular moving and handling on the behavioural and physiological consequences to preslaughter treatment and consequences for subsequent meat quality. J Anim Sci 1998;76:2080-5.

[73] Spoolder HAM, Burbidge JA, Lawrence AB, Simmins PH, Edwards SA. Individual behavioural differences in pigs: intra and inter test consistency. Appl Anim Behav Sci 1996;49:185-98.

[74] Forkman B, Furuhaug IL, Jensen P. Personality, coping patterns, and aggression in piglets. Appl Anim Behav Sci 1995;45:31-42. 
[75] Jones JB, Wathes CM, White RP, Jones RB. Do pigs find a familiar odourant attractive in novel surroundings? Appl Anim Behav Sci 2000;70: $115-26$.

[76] Lawrence AB, Terlouw EMC, Illius AW. Individual differences in behavioural responses of pigs exposed to non-social and social challenges. Appl Anim Behav Sci 1991;30:73-86.

[77] Hessing MJC, Hagelsø AM, Schouten WGP, Wiepkema PR, van Beek JAM. Individual behavioral and physiological strategies in pigs. Physiol Behav 1994;55:39-46.

[78] Janczak AM, Pedersen LJ, Bakken M. Aggression, fearfulness and coping styles in female pigs. Appl Anim Behav Sci 2003;81(1):13-28.

[79] Hayne SM, Gonyou HW. Effects of regrouping on the individual behavioural characteristics of pigs. Appl Anim Behav Sci 2003;82(4): 267-78.

[80] Hutson GD, Ambrose TJ, Barnett JL, Tilbrook AJ. Development of a behavioural test of sensory responsiveness in the growing pig. Appl Anim Behav Sci 2000;66:187-202.

[81] Erhard HW, Mendl M, Christiansen SB. Individual differences in tonic immobility may reflect behavioural strategies. Appl Anim Behav Sci 1999;64:31-46.

[82] Hessing MJC, Hagelsø AM, van Beek JAM, Wiepkema PR, Schouten WPG, Krukow R. Individual behavioural characteristics in pigs. Appl Anim Behav Sci 1993;37:285-95.

[83] van Kooij E, Kuijpers AH, Schrama JW, Ekkel ED, Tielen MJM. Individual behavioural characteristics in pigs and their impact on production. Appl Anim Behav Sci 2000;66:171-85.

[84] Jensen P, Rushen J, Forkman B. Behavioural strategies or just individual variation in behaviour? - a lack of evidence for active and passive piglets. Appl Anim Behav Sci 1995;43:135-9.

[85] Tanida H, Miura A, Tanaka T, Yoshimoto T. Behavioral responses of piglets to darkness and shadows. Appl Anim Behav Sci 1996;49:173-83.

[86] Cheng C, Costall B, Kelly ME, Naylor JR. Action of 5. hydroxytryptophan to inhibit and disinhibit mouse behaviour in the light/dark test. Eur J Pharmacol 1994;225:39-49.

[87] Misslin R, Cigrang M. Does neophobia necessarily imply fear or anxiety? Behav Processes 1986;12(1):45-50.

[88] Caley P. Movements, activity patterns and habitat use of feral pigs (Sus scrofa) in a tropical habitat. Wildless Res 1997;24:77-8.

[89] Russo L, Massei G, Genov PV. Daily home range and activity of wild boar in a mediterranean area free from hunting. Ethol Ecol Evol 1997;9: 287-94.

[90] Braude R, Mitchell KG, Finnkelsey P, Owen VM. The effect of light on fattening pigs. Proc Nutr Soc 1958;17:38.

[91] Fraser AF, Broom DM, editors. Farm animal behaviour and welfare. Wallingford, UK: CAB International; 1997.

[92] Pellow S, Chopin P, File SE, Briley M. Validation of open-closed arm entries in an elevated plus-maze as a measure of anxiety in the rat. J Neurosci Methods 1985;14(3):149-67.

[93] Lister RG. The use of a plus maze to measure anxiety in the mouse. Psychopharmacology 1987;92:180-5.

[94] Janczak AM, Andersen IL, Boe KE, Faerevik G, Bakken M. Factor analysis of behaviour in the porcine and murine elevated plus-maze models of anxiety. Appl Anim Behav Sci 2002;77:155-66.

[95] Janczak AM, Pedersen LJ, Bakken M. Effects of variation in pre-test transport duration and animal age on behaviour in the porcine elevated plus-maze - a brief report. Appl Anim Behav Sci 2002;77(3):233-8.

[96] Janczak AM, Pedersen LJ, Jensen KH, Andersen IL, Bøe KE, Bakken M. No effect of variation in handling on behaviour in a porcine elevated plusmaze - a brief report. Appl Anim Behav Sci 2000;69:169-73.

[97] Moberg GP, Wood VA. Effect of differential rearing on the behavioral and adrenocortical response of lambs to a novel environment. Appl Anim Ethol 1982;8(3):269-79.

[98] Desire L, Veissier I, Despres G, Boissy A. On the way to assess emotions in animals: do lambs (Ovis aries) evaluate an event through its suddenness, novelty, or unpredictability? J Comp Psychol 2004;118(4):363-74.

[99] Erhard HW, Boissy A, Rae MT, Rhind SM. Effects of prenatal undernutrition on emotional reactivity and cognitive flexibility in adult sheep. Behav Brain Res 2004;151(1/2):25-35.
[100] Vandenheede M, Bouissou MF. Fear reactions of ewes to photographic images. Behav Processes 1994;32(1):17-28.

[101] Price EO, Thos J. Behavioral responses to short term social isolation in sheep and goats. Appl Anim Ethol 1980;6(4):331-9.

[102] Torres Hernandez G, Hohenboken W. An attempt to assess traits of emotionality in crossbred ewes. Appl Anim Ethol 1979;5(1):71-83.

[103] Moberg GP, Anderson CO, Underwood TR. Ontogeny of the adrenal and behavioral responses of lambs to emotional stress. J Anim Sci 1980;51(1): $138-42$.

[104] Lachaux M, Bouissou MF, Berges JC, Orgeur RP. Behavior of Ile. de. France rams reared in different conditions in an open-field tests. Biol Behav 1983;8(3):257-69.

[105] Parrott RF, Thornton SN, Robinson JE. Endocrine responses to acute stress in castrated rams: no increase in oxytocin but evidence for an inverse relationship between cortisol and vasopressin. Acta Endocrinol 1988;117(3):381-6.

[106] Parrott RF, Houpt KA, Misson BH. Modification of the responses of sheep to isolation stress by the use of mirror panels. Appl Anim Behav Sci 1988;19(3 4):331-8.

[107] Le Neindre P, Poindron P, Trillat G, Orgeur P. Influence of breed on reactivity of sheep to humans. Genet Sel Evol 1993;25(5):447-58.

[108] Porter RH, Bouissou MF. Discriminative responsiveness by lambs to visual images of conspecifics. Behav Processes 1999;48(1/2):101-10.

[109] Vierin M, Bouissou MF. Influence of maternal experience on fear reactions in ewes. Appl Anim Behav Sci 2002;75(4):307-31.

[110] Le Neindre P, Poindron P, Trillat G, Orgeur P. Influence of breed on reactivity of sheep to humans. Genet Sel Evol 1993;25(5):447-58.

[111] Lyons DM, Price EO, Moberg GP. Individual differences in temperament of domestic dairy goats: constancy and change. Anim Behav 1988;36(5): 1323-33.

[112] Lyons DM, Price EO. Relationships between heart rates and behavior of goats in encounters with people. Appl Anim Behav Sci 1987;18(3/4): 363-9.

[113] Kilgour RJ, Szantar-Coddington MR. Arena behaviour of ewes selected for superior mothering ability differs from that of unselected ewes. Anim Reprod Sci 1995;37(2):133-41.

[114] Boivin X, Boissy A, Nowak R, Henry C, Tournadre H, Le Neindre P. Maternal presence limits the effects of early bottle feeding and petting on lambs' socialisation to the stockperson. Appl Anim Behav Sci 2002;77(4):311-28.

[115] Jones RB. Fear and adaptability in poultry: insights, implications and imperatives. Worlds Poult Sci J 1996;52:131-74.

[116] Gallup Jr GG, Suarez SD. An ethological analysis of open-field behaviour in chickens. Anim Behav 1980;28:368-78.

[117] Suarez SD, Gallup Jr GG. Social reinstatement and open-field testing in chickens. Anim Learn Behav 1983;11(1):119-26.

[118] Jones RB. Open field behaviour in domestic chicks (Gallus domesticus): the influence of the experimenter. Biol behav 1987;12:100-15.

[119] Jones RB, Carmichael NL. Open field behavior in domestic chicks tested individually or in pairs: differential effects of painted lines delineating subdivisions of the floor. Behav Res Methods Instrum Comput 1997;29(3): $396-400$.

[120] Jones RB, Faure JM. Open field behaviour of male and female domestic chicks as a function of housing conditions, test situations and novelty. Biol behav 1982;7:17-25.

[121] Jones RB, Merry BJ. Individual or paired exposure of domestic chicks to an open field: some behavioural and adrenocortical consequences. Behav Processes 1988;16:75-86.

[122] Salvatierra NA, Arce A. Day-old chicks categorised on latency to peck, exhibit a stable fear pattern until 15 days of age. Appl Anim Behav Sci 2001;73:103-16.

[123] Heiblum R, Aizenstein O, Gvaryahu G, Voet H, Robinzon B, Snapit N. Tonic immobility and open field responses in domestic fowl chicks during the first week of life. Appl Anim Behav Sci 1998:347-57.

[124] Hocking PM, Channing CE, Waddington D, Jones RB. Age-related changes in fear, sociality and pecking behaviours in two strains of laying hen. Br Poult Sci 2001;42:414-23.

[125] Jones RB, Waddington D. Modification of fear in domestic chicks, Gallus gallus domesticus, via regular handling and early environmental enrichment. Anim Behav 1992;43:1021-33. 
[126] Moriarty DD. Anxiogenic effects of a beta-carboline on tonic immobility and open field behaviour in chickens (Gallus gallus). Pharmacol Biochem Behav 1995;51(4):795-8.

[127] Jones RB, Blokhuis HJ, Beuving G. Open field and tonic immobility responses in domestic chicks of two genetic lines differing in their propensity to feather peck. Br Poult Sci 1995;36:525-30.

[128] Moriarty Jr DD, Roberts KA, Allen JL, Hennig CW. Anticholinergic drugs and open field behavior in chickens. Bull Psychon Soc 1988;26(6): $559-62$.

[129] Jones RB. Sex and strain differences in the open field responses of the domestic chick. Appl Anim Ethol 1977;3:255-61.

[130] Jones RB, Bessei W, Faure JM. Aspects of fear in Japanese quail chicks (Coturnix coturnix japonica) genetically selected for different levels of locomotor activity. Behav Processes 1982;7:201-10.

[131] Jones RB, Mills AD, Faure JM. Genetic and experiential manipulation of fear-related behavior in Japanese quail chicks (Coturnix coturnix japonica). J Comp Psychol 1991;105:15-24.

[132] Jones RB, Satterlee DG, Ryder FH. Fear and distress in Japanese quail chicks of two lines genetically selected for low or high adrenocortical response to immobilization stress. Horm Behav 1992;6:385-93.

[133] Rodenburg TB, Buitenhuis AJ, Ask B, Uitdehaag KA, Koene P, van der Poel JJ, et al. Heritability of feather pecking and open-field response of laying hens at two different ages. Poult Sci 2003;82:861-7.

[134] Buitenhuis AJ, Rodenburg TB, Siwek M, Cornelissen JJB, Nieuwland MGB, Crooijmans RPMA, et al. Identification of QTLs involved in openfield behavior in young and adult laying hens. Behav Genet 2004;34(3): $325-33$.

[135] Jones RB. Fear responses of individually caged laying hens as a function of cage level and aisle. Appl Anim Behav Sci 1985;14:63-74.

[136] Jones RB. Fearfulness of hens caged individually or in groups in different tiers of a battery and the effects of translocation between tiers. Br Poult Sci 1985;26:399-408.

[137] Barnett JL, Hemsworth PH. Fear of humans by laying hens in different tiers of a battery: behavioural and physiological responses. Br Poult Sci 1989;30:497-502.

[138] Jones RB, Andrew RJ. Responses of adult domestic cocks and capons to novel and alarming stimuli. Behav Processes 1992;26:189-200.

[139] Jones RB, Satterlee DG, Moreau J, Waddington D. Vitamin C supplementation and fear-reduction in Japanese quail: short-term cumulative effects. Br Poult Sci 1996;37:33-42.

[140] Jones RB, Satterlee DG, Marks HL. Fear-related behaviour in Japanese quail divergently selected for body weight. Appl Anim Behav Sci 1997;52: 87-98.

[141] Sargent AB, Eberhardt LE. Death feigning by ducks in response to predation by red foxes (Vulpes fulva). Am Midl Nat 1975;94(1): $108-19$.

[142] Thompson RKR, Foltin RW, Boylan RJ, Sweet A, Graves CA, Lowitz CE. Tonic immobility in Japanese quail can reduce the probability of sustained attack by cats. Anim Learn Behav 1981;9(1):145-9.

[143] Jones RB, Faure JM. Sex and strain comparisons of tonic immobility ("righting time") in the domestic fowl and the effects of various methods of induction. Behav Processes 1981;6:47-55.

[144] Jones B. The tonic immobility reaction of the domestic fowl: a review. Worlds Poult Sci J 1986;42(1):82-96.

[145] Gallup Jr GG, Cummings WH, Nash RF. The experimenter as an independent variable in studies of animal hypnosis in chickens (Gallus gallus). Anim Behav 1972;20:166-9.

[146] Jones RB. Experimenter visibility, spectacles and tonic immobility in the domestic fowl. Appl Anim Behav Sci 1989;22:371-5.

[147] Bilĉik B, Keeling LJ, Newberry RC. Effect of group size on tonic immobility in laying hens. Behav Processes 1988;43:53-9.

[148] Jones RB, Faure JM. Tonic immobility in the domestic fowl as a function of social rank. Biol Behav 1982;7:27-32.

[149] Jones RB, Faure JM. The effects of regular handling on fear responses in the domestic chick. Behav Processes 1981;6:135-48.

[150] Jones RB, Waddington D. Attenuation of the domestic chick's fear of human beings via regular handling: in search of a sensitive period. Appl Anim Behav Sci 1993;36:185-95.
[151] Marin RH, Freytes P, Guzman D, Jones RB. Effects of an acute stressor on fear and on the social reinstatement responses of domestic chicks to cagemates and strangers. Appl Anim Behav Sci 2001;71:57-66.

[152] Jones RB. The nature of handling immediately prior to test affects tonic immobility fear reactions in laying hens and broilers. Appl Anim Behav Sci 1992;34:247-54.

[153] Satterlee DG, Jones RB, Ryder FH. Short-latency stressor effects on tonic immobility fear reactions of Japanese quail divergently selected for adrenocortical responsiveness to immobilization. Poult Sci 1993;72:1132-6.

[154] Jones RB, Mills AD, Faure JM, Williams JB. Restraint, fear, and distress in Japanese quail genetically selected for long or short tonic immobility reactions. Physiol Behav 1994;56:529-34.

[155] Jones RB, Satterlee DG. Fear in aged quail divergently selected for adrenocortical responsiveness. In: Koene P, Blokhuis HJ, editors. Proc. 5th european symposium on poultry welfare, WAU. The Netherlands: DLO; 1997. p. 161-2.

[156] Schütz KE, Kerje S, Jacobsson L, Forkman B, Carlborg Ö, Andersson L, et al. Major growth QTLs in fowl are related to fearful behavior: possible genetic links between fear responses and production traits in a red junglefowl $\mathrm{x}$ white leghorn intercross. Behav Genet 2004;34(1):121-30.

[157] Schütz K, Forkman B, Jensen P. Domestication effects on foraging strategy, social behaviour and different fear responses: a comparison between the red junglefowl (Gallus gallus) and a modern layer strain. Appl Anim Behav Sci 2001;74:1-14.

[158] Ratner SC, Thompson RW. Immobility reactions (fear) of domestic fowl as a function of age and prior experience. Anim Behav 1960;8:181-91.

[159] Jones RB, Satterlee DG, Cadd GG. Timidity in Japanese quail: effects of vitamin $\mathrm{C}$ and divergent selection for adrenocortical response. Physiol Behav 1999;67:117-20.

[160] Seaman SC, Davidson HPB, Waran NK. How reliable is temperament assessment in the domestic horse (Equus caballus)? Appl Anim Behav Sci 2002;78:175-91.

[161] Wolff A, Hausberger M, Le Scolan N. Experimental tests to assess emotionality in horses. Behav Processes 1997;40:209-21.

[162] Le Scolan N, Hausberger M, Wolff A. Stability over situations in temperament traits of horses as revealed by experimental and scoring approach. Behav Processes 1997;41:209-21.

[163] Momozawaa Y, Onob T, Satoc F, Kikusuia T, Takeuchia Y, Moria Y, et al Assessment of equine temperament by a questionnaire survey to caretakers and evaluation of its reliability by simultaneous behavior test. Appl Anim Behav Sci 2003;84:127-38.

[164] Visser EK, van Reenen CG, Rundgren M, Zatterqvist M, Morgan K, Blokhuis HJ. Responses of horses in behavioural tests correlate with temperament assessed by riders. Equine Vet J 2003;35(2):176-83.

[165] Visser EK, van Reenen CG, van der Werf JTN, Schilder MBH, Knaap JH, Barneveld A, et al. Heart rate and heart rate variability during a novel object test and a handling test in young horses. Physiol Behav 2002;76:289-96.

[166] Visser EK, van Reenen CG, Hopster H, Schilder MBH, Knaap JH, Barneveld A, et al. Quantifying aspects of young horses' temperament: consistency of behavioural variables. Appl Anim Behav Sci 2001;74: $241-58$.

[167] Anderson MK, Friend TH, Evans JW, Bushong DM. Behavioral assessment of horses in therapeutic riding programs. Appl Anim Behav Sci 1999;63:11-24.

[168] Jezierski T, Jaworski Z, Gorecka A. Effects of handling on behaviour and heart rate in Konik horses: comparison of stable and forest reared youngstock. Appl Anim Behav Sci 1999;62:1-11.

[169] Mikkelsen J, Lund JD. Euthanasia of dogs because of behavioural problems. An epidemiological study on euthanasia of dogs in Denmark with particular reference to aggression problems. Dan Vettidsskr 1999;82: 474-9.

[170] Hydbring-Sandberg E, Winblad von Walter L, Höglund K, Svartberg K, Swenson L, Forkman B. Physiological reactions to fear provocation in dogs. J Endocrinol 2004;180:439-48.

[171] Svartberg K, Forkman B. Personality traits in the domestic dog (Canis familiaris). Appl Anim Behav Sci 2002;79:133-57.

[172] Svartberg K, Tapper I, Temrin H, Radesäter T, Thorman S. Consistency of personality traits in dogs. Anim Behav 2005;69:283-91. 